\title{
A revision of the bee genus Ceratina, subgenus Rhysoceratina (Hymenoptera, Apidae, Xylocopinae)
}

\author{
Arturo ROIG-ALSINA \\ Museo Argentino de Ciencias Naturales "Bernardino Rivadavia”, Av. A. Gallardo 470, C1405DJR Buenos Aires, \\ Argentina. E-mail: arturo@macn.gov.ar

\begin{abstract}
The subgenus Rhysoceratina of Ceratina is restricted to South America, with known species in Argentina, Brazil, Colombia, Paraguay, and Uruguay. Nine species are recognized, four of which are described as new: C. canaliculata, C. pusilla, C. mendozina, and C. nitidifrons. Lectotypes are designated for C. catamarcensis Schrottky, 1907, and C. volitans Schrottky, 1907. A phylogenetic analysis supports the monophyly of the subgenus and, within it, of two major species groups. A key to the species, descriptions, distributional data, and illustrations are provided.
\end{abstract}

Key words: Small carpenter bees, Apiformes, Systematics, South America.

Resumen: Revisión del género de abejas Ceratina, subgénero Rhysoceratina (Hymenoptera, Apidae, Xylocopinae). El subgénero Rhysoceratina de Ceratina está restringido a América del Sur, con especies conocidas de Argentina, Brasil, Colombia, Paraguay y Uruguay. Se reconocen nueve especies, de la cuales cuatro se describen como nuevas: C. canaliculata, C. pusilla, C. mendozina y C. nitidifrons. Se designa lectotipos para $C$. catamarcensis Schrottky, 1907, y para C. volitans Schrottky, 1907. El análisis filogenético apoya la monofilia del subgénero y dentro de él de dos grupos principales de especies. Se presenta una clave de especies, descripciones, datos de distribución e ilustraciones.

Palabras clave: Abejas carpinteras menores, Apiformes, Sistemática, Sudamérica.

\section{INTRODUCTION}

The genus Ceratina Latreille, single member of the tribe Ceratinini, has a world-wide distribution and it is diverse both in the Eastern and the Western Hemispheres. Michener (2007) recognized 21 subgenera, of which five are exclusively from the Americas: Zadontomerus Ashmead, with maximal diversity in North America, although a few species reach northern South America, Crewella Cockerell, with maximal diversity in South America, although its species extend north to Mexico, Calloceratina Cockerell, with maximal diversity in Central America, but with a few species reaching as far south as northern Argentina, Ceratinula Moure, distributed from southern United States to central Argentina, and Rhysoceratina Michener, restricted to South America. Another subgenus, Neoclavicera Roig-Alsina, has been recently proposed for a group of species also restricted to South America (Roig-Alsina, 2013).
The relationships within Ceratina have been studied by Rehan et al. (2010) on the basis of one nuclear and two mitochondrial genes. These authors included representatives of 14 of the known subgenera, among them the New World Zadontomerus, Ceratinula, and Calloceratina. These three subgenera resulted closely related in the analysis, forming a clade together with the Oriental subgenera Ceratinidia Cockerell and Lioceratina Vecht. Of the remaining New World subgenera, Crewella may well be suspected to belong in the same clade, based on its close morphological affinities with Calloceratina, but the relationships of Rhysoceratina remain unknown.

The subgenus Rhysoceratina was proposed by Michener (2000) to include a distinctive group of South American Ceratina which bear a transverse preapical carina on the sixth metasomal tergum of the female. The subgenus is also characterized by the strongly punctate body, the presence of a preoccipital carina, the basitibial plate of the female indicated by a strong tooth, the seventh tergum of the male with a midapical 
marginal projection, and by the presence of graduli on the second to fourth metasomal terga and second to third metasomal sterna of both sexes. According to Michener (2000), J. S. Moure had recognized the group, and "Rhysoceratina" was left as an unpublished name in collections. This name was used as a nomen nudum, for C. volitans Schrottky and C. stilbonota Moure, by Sakagami \& Laroca (1971). The group was also recognized by Hirashima (1971), without naming it, as one of two New World groups with wax plates restricted to the female second sternum, other groups having wax plates on the second and third sterna. The other group of New World species with wax plates restricted to the second sternum is Neoclavicera, which has been recently revised by Roig-Alsina (2013).

Most species of Rhysoceratina are known from Argentina and southeastern Brazil, but they also occur in Uruguay and Paraguay, and one species is newly described here from Colombia. Moure (2007), in his catalog of Neotropical bees, recognized five species within Rhysoceratina; four of these are considered valid in the present contribution. Ceratina correntina Schrottky, unplaced to subgenus to date, is shown to be also a member of the subgenus, and four species are described as new, totaling the number of species to nine.

Information on the biology of species of Rhysoceratina is scarce. Besides a few notes on flower visitation (Holmberg, 1886; Jörgensen, 1909, 1912a, 1912b; Schlumpberger et al., 2009) the only available work is the study of Sakagami \& Laroca (1971) on the nesting biology of Ceratina volitans Schrottky in southern Brazil. They described the nest structure and partitions, the pollen loaves and the eggs on them, and recorded duration of immature stages, phenological data, plants used as nest substrata, and flower visits.

\section{MATERIAL AND METHODS}

Specimens studied are deposited in the following institutions: California Academy of Sciences, San Francisco (CAS); Facultad de Ciencias, Universidad de la República, Montevideo (FCM); Instituto y Fundación Miguel Lillo, Tucumán (IFML); Museo Argentino de Ciencias Naturales "Bernardino Rivadavia," Buenos Aires (MACN); Museo de La Plata, La Plata (MLP); Natural History Museum, London (London). Acronyms are used to indicate depositories of the specimens.

The following abbreviations are used. The maximum diameter of the median ocellus (MOD) is used as a reference to express the length of the pubescence and other structures. The metasomal terga (T) and sterna (S) are identified with Arabic numerals. The sex of the specimens is indicated by $\mathrm{F}$, female, and $\mathrm{M}$, male.

The phylogenetic analysis and the illustration of the cladogram were made with the aid of the programs TNT, v. 1.1 (Goloboff et al., 2003) and Mesquite (Maddison \& Maddison, 2016). For outgroup comparison the following species were included in the analysis: $C$. (Ceratinula) oxalidis Schrottky, C. (Ceratinula) arizonensis Cockerell, C. (Zadontomerus) calcarata Robertson, C. (Zadontomerus) acantha Provancher, C. (Neoclavicera) parvimacula Roig Alsina, and C. (Neoclavicera) richardsoniae Schrottky.

\section{SYSTEMATICS}

\section{Rhysoceratina}

\section{Rhysoceratina Michener, 2000: 599. Type spe-} cies: Ceratina montana, Holmberg, 1886.

Diagnosis. Small species 4.8-8.5 mm long, with black to weakly metallic integument and yellow marks restricted to head, pronotal lobe and legs. Paraocular areas with punctures at least along the inner margin of eyes, but extensively punctate in most species; ocellocular areas always punctate. Circumantennal area shallowly depressed. Preoccipital carina present. Mandible of male with two teeth. Pronotum with dorsolateral angle rounded to weakly carinate; lateral carina absent, or present below the transpronotal sulcus in a species group. Basal area of the metapostnotum slightly depressed, rugose or rugoso-striate, longer than metanotum. Anterior and middle tibiae with single dorsoapical tooth. Basitibial plate of female indicated by strong tooth. Sixth tergum of female with strong transverse preapical carina and weak median longitudinal impression. Metasomal graduli present on second to fourth terga and second to third sterna of both sexes. Wax plate present on female second sternum. Seventh tergum of male with midapical marginal projection.

\section{Phylogenetic analysis}

The analysis was based on 25 morphological characters, listed below. Table 1 is a data matrix of character states for the nine species of Rhysoceratina and the six species of other subgenera selected as outgroups. Trees were calculated with the implicit enumeration algorithm 


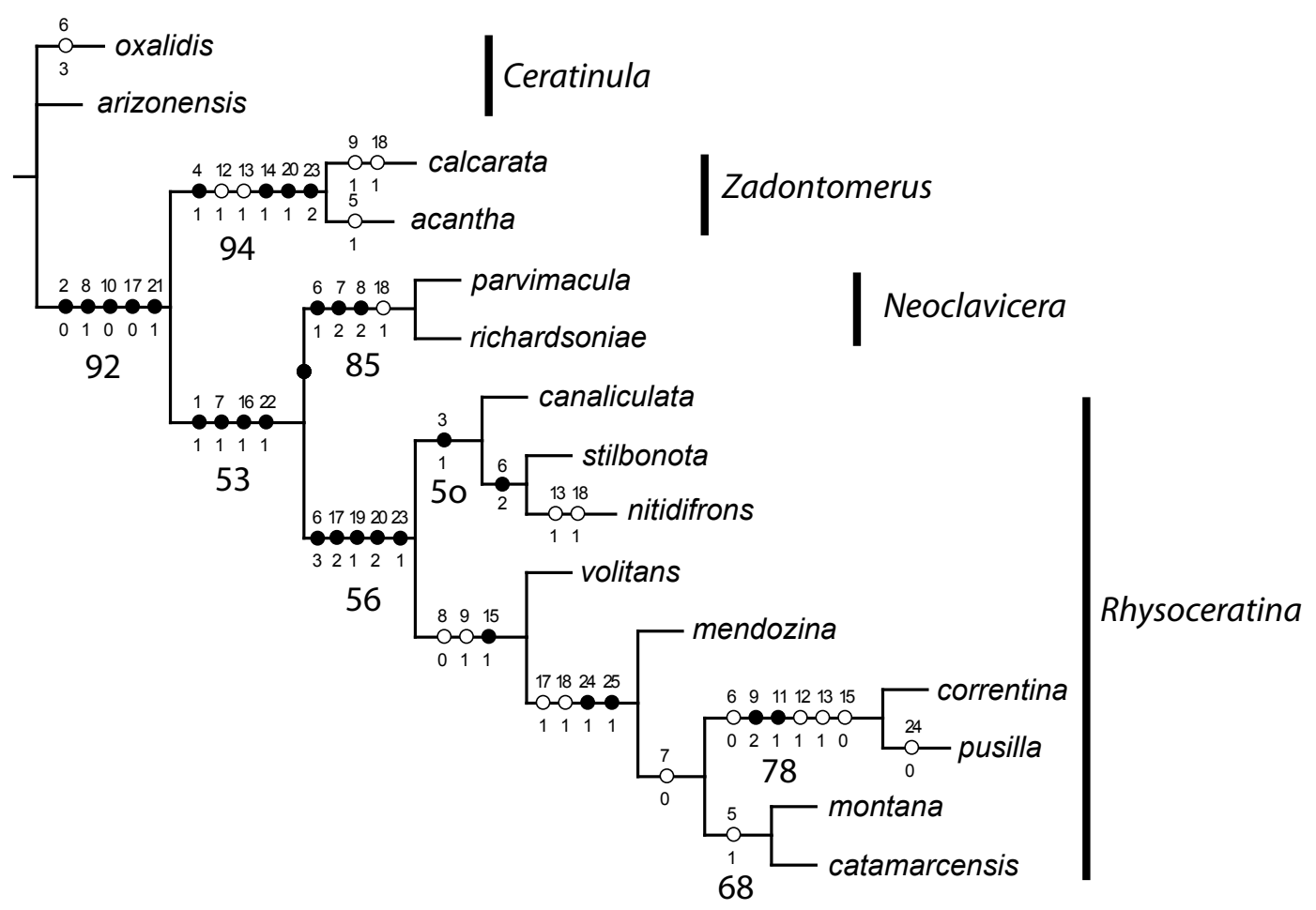

Fig. 1. Relationships among species of Rhysoceratina based on morphological characters. Black hash marks indicate nonhomoplastic changes. Large numbers below branches indicate bootstrap values. Subgenera indicated at right.

implemented in TNT, using unordered, unweighted characters. A single most parsimonious, fully resolved tree was obtained (length 48 steps, Fig. 1). Standard bootstrap (1000 replicates) values are shown below branches in figure 1 . The resampling procedure collapses the branch leading to volitans and the montana species group, resulting in a tricotomy, and mendozina is shown as sister to montana and catamarcensis.

According to the analysis, two species groups can be recognized within the subgenus Rhysoceratina. The canaliculata species group, which also includes stilbonota and nitidifrons, is characterized by the peculiar channel-like, longitudinal depression of the paraocular area below the antennal socket, present in both sexes. The three species have a distinct lateral pronotal carina below the transpronotal sulcus, and an impunctate disc of the scutum behind the admedian lines, but these are plesiomorphic conditions for Rhysoceratina as a whole in the present analysis. The montana species group, which also includes mendozina, catamarcensis, pusilla, and correnti$n a$, is supported by two characteristics of the males: the dense sternal fringes on the apical margin of S4 and S5 (although lost in pusilla), and the sparsely punctate, depressed areas on S6. Ceratina volitans is intermediate between the two groups, sharing with canaliculata and allied species a peculiar depressed $\mathrm{T} 5$ in the female, but lacking a lateral pronotal carina and having an extended pilosity on the male hind femur as in the montana group.

\section{List of characters}

1. Preoccipital margin. (0) rounded. (1) carinate.

2. Paraocular area above level of antennal socket. (0) punctate. (1) smooth.

3. Paraocular area next to subantennal and epistomal sutures. (0) punctate, not depressed. (1) impunctate, smooth or microsculptured, depressed, forming a trough.

4. Impunctate swollen areas on frons. (0) absent. (1) present.

5. Clypeus of female. (0) with yellow mark. (1) dark.

6. Gena of female, marks close to posterior magin of eye. (0) black, no marks. (1) yellow stripe on upper third. (2) yellow mark near middle of eye. (3) yellow to dark brown mark on lower third. 
7. Dorsolateral angle of pronotum. (0) rounded. (1) weakly carinate dorsally, but carina not continuing laterally to transpronotal sulcus. (2) strongly carinate, carina continuing laterally to transpronotal sulcus.

8. Lateral pronotal carina. (0) absent. (1) present, carinate. (2) present, lamellate.

9. Disc of scutum of female, area between end of admedian lines and posterior punctate band. (0) impunctate. (1) with few punctures along parapsidal furrows and continuing admedian lines (Fig. 2A). (2) densely punctate (Fig. 2B).

10. Basal area of metapostnotum. (0) rugosostriate. (1) granulate.

11. Venter of male mesothorax, paramedian sparsely punctate swellings anterior to median depression. (0) absent. (1) present.

12. Forecoxa of female, basal carina. (0) present. (1) absent.

13. Forecoxa of female, lateral projection. (0) mucronate. (1) rounded.

14. Hind femur of male, angulate ventral projection. (0) absent. (1) present.

15. Hind femur of male, brush of hairs on ventral surface. (0) on basal half of femur, or less. (1) on basal 0.6 or more.

16. T5 of female, gradulus. (0) present. (1) absent.

17. T5 of female, shape. (0) convex to weakly convex. (1) medially flattened. (2) medially depressed.

18. T5 of female, sculpture. (0) Coarse sculpture nearly reaching apical magin, separated from margin at most by a row of punctures. (1) Coarse sculpture separated from margin by smooth area with scattered punctures.

19. T6 of female, lateral carina. (0) absent. (1) present.
20. T6 of female, median depressions. (0) absent. (1) with preapical rounded depression. (2) with longitudinal median depression.

21. S5 of female, gradulus. (0) present. (1) absent.

22. Sterna of female, wax plates. (0) present on S2 and S3. (1) present on S2 only.

23. T7 of male, shape of apical margin. (0) convex to truncate, without median projections. (1) with median pointed projection. (2) with apical projection broad and short, 2 or more times broader than long. (3) forming an apical plate (Daly, 1973).

24. S4 and S5 of male, apical fringes. (0) hairs sparse, not forming definite fringes. (1) with distinct apical fringes.

25. S6 of male, preapical paramedian depressed areas with punctures sparser than on surrounding areas. (0) absent. (1) present.

Table 1. Data matrix for phylogenetic analysis.

oxalidis $\quad 0100030001000000100000000$

arizonensis $\quad 0100000001000000100000000$

calcarata $\quad 0001000110011100010110200$

acantha $\quad 0001100100011100000110200$

montana 10001[03]0010000011111211111

catamarcensis 1000130010000011111211111

correntina $\quad 1000000020111001111211111$

pusilla $\quad 1000000020111001111211101$

mendozina $\quad 1000031010000011111211111$

volitans $\quad 1000031010000011201211100$

stilbonota $\quad 1010021100000001201211100$

canaliculata 1010031100000001201211100

nitidifrons $\quad 1010021100001001211211100$

parvimacula 1000012200000001010011000

richardsoniae 1000012200000001010011000

\section{Key to species of Ceratina subgenus Rhysoceratina}

\section{Females}

1.- Paraocular area next to subantennal and epistomal sutures depressed, impunctate, smooth or microsculptured, forming a trough reaching below to level of tentorial pit; this trough 0.4-0.6 times as wide as paraocular area (Figs. 5A-C). Pronotal lateral carina distinct below transpronotal sulcus. (canaliculata species group)

-- Paraocular area with punctures next to epistomal suture; below antennal insertion at most with impunctate triangular area which tapers down along subantennal suture (Figs. 4A-F). Pronotal lateral carina absent or vestigial below transpronotal sulcus. (montana species group)..4

2.- Cuticle above antennal socket highly polished, impunctate (Fig. 5B). Lateral projection of forecoxa with apex rounded, bent posteriorly. nitidifrons

-- Cuticle above antennal socket dull, microsculptured, with punctures reaching close to socket (Figs. 5A, 5C). Lateral projection of forecoxa with mucronate lateral projection (similar to Fig. $3 \mathrm{~A})$. 
3.- Pronotal lobe black. Foretibia dark, as remainder of legs; at most foretibia with poorly defined dark reddish-brown upper stripe. T4-T5 with slender setae (as in Figs. 2E-F). stilbonota

.- Pronotal lobe with yellow spot. Foretibia with distinct yellow upper stripe. T4-T5 with broadened setae (as in Fig. 2D) canaliculata

4.- Clypeus dark, without yellow marks. . .5

.- Clypeus with yellow marks.....

5.- Yellow of paraocular area forming short spot at level of antennal insertion (Fig. 4A). Wings weakly infuscate, with dark brown veins. Gena usually black, though in some specimens a very dark brown spot can be seen. T4-T5 with slender setae (Fig. 2E). montana

.- Yellow of paraocular area forming band reaching below to lateral lower angle of clypeus (Fig. 4B). Wings yellowish brown, with yellowish brown veins. Gena usually with yellow spot, though spot sometimes brownish. T4-T5 with broadened setae (as in Fig 2D). catamarcensis

6.- T4-T5 with slender setae (Fig. 2F), at most with some setae with broadened apices at sides of T5. Scutum with dense punctures between notaulus and admedian lines (punctures separated by less than their diameter, Fig. 2B); disc of scutum with numerous punctures between the end of admedian lines and posterior punctate band (Fig. 2B).

.- T4-T5 with broadened setae (Fig. 2D). Scutum with sparse punctures between notaulus and admedian lines (punctures separated by 1-2 times their diameter, Fig. 2A); disc of scutum with few or no punctures between the end of admedian lines and posterior punctate band (Fig. 2A)..8

7.- Lateral projection of forecoxa with anterior margin weakly concave and posterior margin sinuose (Fig. 3B). Yellow of paraocular area forming fusiform mark, pointed below, not reaching margin of clypeus (Fig. 4C). Body with bluish tints. pusilla

.- Lateral projection of forecoxa with rounded apex, anterior and posterior margins convex (Fig. 3C). Yellow of paraocular area forming band reaching below to lateral lower angle of clypeus (Fig. 4D). Body with olive-green tints. .correntina

8.- Yellow paraocular band broad, above nearly reaching antennal socket (Fig. 4E). T5 with dense punctures close to apical margin (punctures separated from margin by aproximately their diameter, Fig. 2C). T5 medially flattened. mendozina

.- Yellow paraocular band narrow, above separated from antennal socket by half socket diameter or more (Fig. 4F). T5 with apical median area with sparse punctures and large interspaces. T5 medially with two apical thirds depressed. volitans

\section{Males}

1.- Paraocular area close to subantennal and epistomal sutures depressed, impunctate, smooth or microsculptured, forming a trough reaching below to level of tentorial pit; such a trough 0.4-0.6 times as wide as paraocular area (Fig. 5D). S4-S5 with apical hairs not forming definite fringes (canaliculata species group).

-- . Paraocular area with punctures close to epistomal suture; below antennal insertion with impunctate triangular area which tapers down along subantennal suture (Figs. 5E-F). Usually S4-S5 with well-defined apical fimbriae (exception is pusilla, with sparse apical hairs on S4S5) (montana species group)

2.- Pronotal lobe black. Hairs on ventral side of mesothorax, in front of middle coxae, long, 1.01.7 times MOD. stilbonota

.- . Pronotal lobe with yellow spot. Hairs on ventral side of mesothorax, in front of middle coxae, short, 0.5-0.7 times MOD. 
3.- Cuticle above and on outer side of antennal socket highly polished, impunctate. Forecoxa and under surface of propleuron with well defined punctures, similar to those of scutum. .nitidifrons

-- . Cuticle above and on outer side of antennal socket dull, microsculptured, above with punctures nearly reaching socket. Forecoxa and under surface of propleuron with shallow, small punctures, much smaller than those of scutum. canaliculata

4.- Scutum densely punctate, disc of scutum with numerous punctures between end of admedian lines and posterior punctate band (as in Fig. 2B). T7 with apical projection broad and short (Figs. 7B-C).

.- . Scutum sparsely punctate, disc of scutum with few punctures (as in Fig. 2A), or no punctures between the end of admedian lines and posterior punctate band. Apical projection of T7 variable.

5.- S5 with dense apical fimbria formed by several rows of hairs. S6 with deep apical notch and paramedian preapical depression drop-shaped (Fig. 6C). correntina

.- . S5 with apical fimbria formed by single row of hairs. S6 with moderate apical notch and paramedian preapical depression indistinct (Fig. 6D). ..pusilla

6.- T7 with apical projection broad and short, truncate, twice or more times broader than long (Fig. 7D). Foretibia and basitarsus (besides yellow marks) yellowish brown, in particular inner side. mendozina

.- . T7 with apical projection pointed or rounded (Figs. 7A, 7E-F), usually as long as broad. Foretibia and basitarsus (besides yellow marks) dark brown to black

7.- Forewing with costal and radial veins yellowish brown. T7 with strong apical projection with rounded apex (Fig. 7E) catamarcensis

.- . Forewing with veins dark brown. T7 with apical projection pointed (Figs. 7A, 7F). .8

8.- Disc of scutum with sparse punctures between end of admedian lines and posterior punctate band. Scutellum with punctures dense, leaving no impunctate areas on disc. S4-S5 with dense apical fimbriae formed by several rows of hairs. montana

.- . Disc of scutum impunctate between end of admedian lines and posterior punctate band. Scutellum with punctures on disc leaving some shiny interspaces among them, which are larger than a puncture diameter. S4-S5 with apical fimbriae formed by single row of hairs.....

volitans

\section{Ceratina (Rhysoceratina) canaliculata} n. sp.

(Figs. 5C-D, 6H, 7G)

Diagnosis. This species is closely related to C. stilbonota, from which it is separated by the yellow mark on the pronotal lobe in both sexes, the dark gena of the female, the broadened setae on the female T4-T5, and the short vestiture of the male, the ventral hairs in front of the mid coxa being 0.5-0.7 times MOD (these hairs in $C$. stilbonota being 1.0-1.7 times MOD). Ceratina canaliculata has been collected in the same places and at the same time as $C$. volitans, to which it is similar in size and color pattern. Besides the features mentioned in the key, canaliculata is separated by the sparser punctation the of ocellocular area and the nearly impunctate lower $2 / 3$ of the gena.

Female. Length, $5.0 \mathrm{~mm}$ (holo and paratype); length of forewing, 3.9-4.2 $\mathrm{mm}$ (holotype $3.9 \mathrm{~mm}$ ). Color. Black, with dark bluish metallic tints, and coppery reflections on supraclypeal area. Tegula brown. Clypeus with dark brown apical band, and triangular yellow mark reaching above to level of tentorial pits. Paraocular yellow mark long (holotype, 0.75 times eye length; paratype, 0.72), reaching below lateral lower angle of clypeus and surpassing above antennal socket; mark narrower than diameter of antennal socket, not touching inner orbit of eye. Gena with dark 

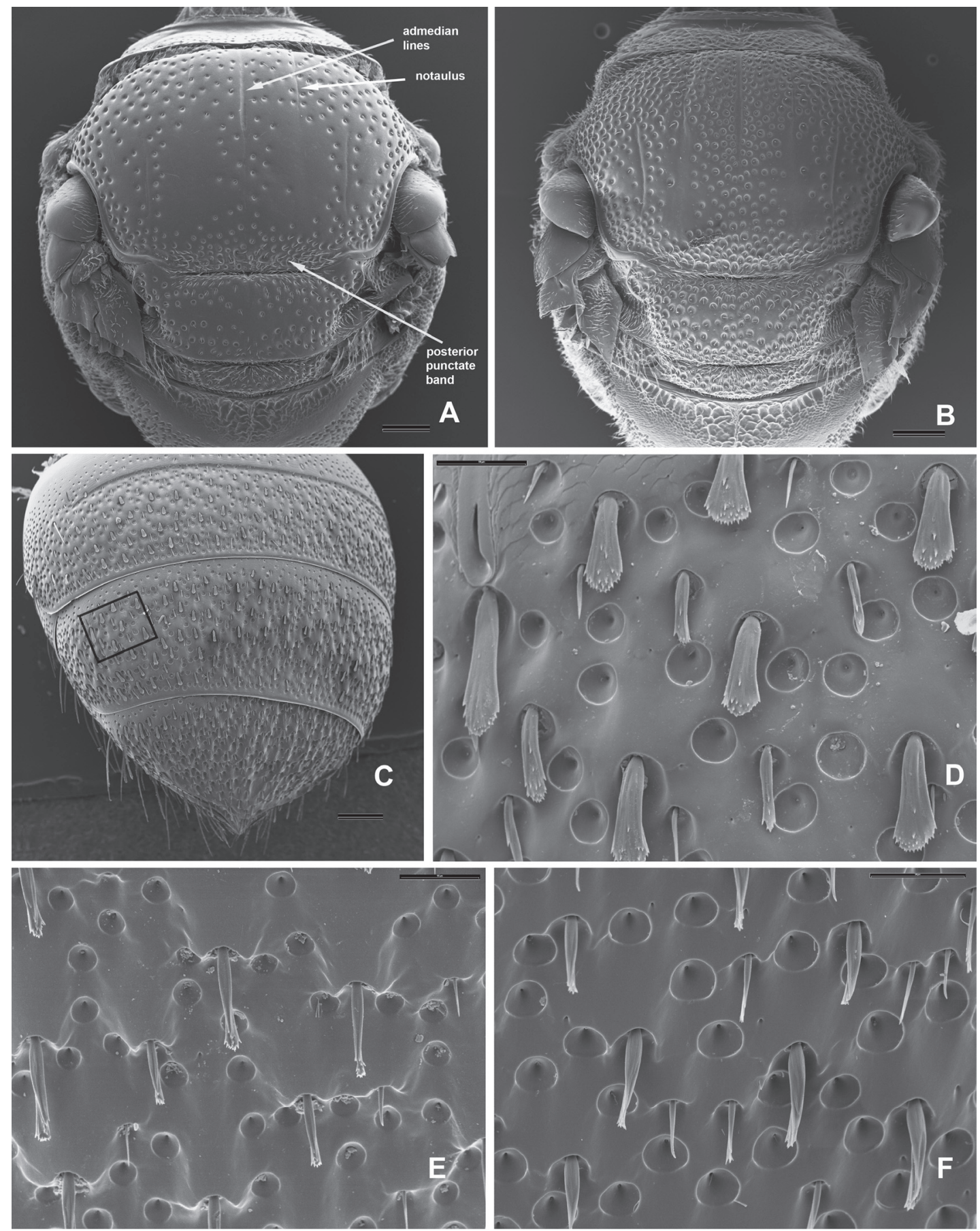

Fig. 2. A, C. mendozina, mesosoma. B, C. pusilla, mesosoma. C, C. mendozina, metasomal terga 3-6 (rectangular inset enlarged in figure D). D, C. mendozina, metasomal setae on T5. E, C. montana, metasomal setae on T5. F, C. correntina, metasomal setae on T5. Scale bars, A-C: $200 \mu$; D-F: $50 \mu$.

brown mark close to lower third of eye. Pronotal lobe with yellow spot. Legs dark brown beyond trochanters, tarsi paler; forefemur with apical yellow spot; foretibia with basal yellow spot followed by yellow stripe. Wings evenly infuscate; veins and pterostigma brown. Structure. 
Paraocular area next to subantennal and epistomal sutures depressed, impunctate, smooth or microsculptured, forming a trough reaching below to level of tentorial pit; such a trough 0.5 times as wide as paraocular area. Distance between lateral ocellus and preoccipital carina 1.45 times ocellar diameter. Ocellocular area with few, irregularly distributed punctures, with interspaces as large as a puncture diameter. Gena with lower two thirds nearly impunctate, close to upper half of eye with irregular, longitudinal row of punctures separated from eye by 3-5 puncture diameters. Proportion between length of eye and length of second segment of labial palpus 1:0.60. Dorsolateral angle of pronotum carinate; lateral carina distinct below transpronotal sulcus. Anterior surface of pronotum entirely punctate, punctures reaching dorsolateral angle. Scutum between admedian line and notaulus with punctures irregularly distributed, separated by 0.5-2.0 times their diameter, interspaces shiny; disc of scutum posteriorly to admedian lines impunctate, or with a few punctures inmediately following lines. Scutellum with punctures sparse medially, leaving transverse impunctate band. Dorsal area of metapostnotum rugulose, basally with short rugae, irregular medially and reaching posterior margin. Forecoxa with basal carina; lateral projection of forecoxa with apex squarish, mucronate, anterior margin concave and posterior margin sinuous. T4-T5 with broadened setae. T5 near to apical margin with median area of sparse punctures. T5 medially with apical two thirds depressed, and base of tergum abruptly elevated. T6 with weak longitudinal median impression.

Male. Length, 5.0-5.2 $\mathrm{mm}$; length of forewing 3.8-4.0 mm. Color. Similar to that of female, with following parts yellow: long paraocular band, extended from lateral lower angle of clypeus to level of antennal socket, but tapering above, being very narrow (sometimes filiform) at level of antennal socket; inverted T-shaped mark on clypeus, pointed above, not reaching above half of clypeus; triangular spot on base of mandible; basal spot on labrum; spot on pronotal lobe; forefemur with apical spot; foretibia and forebasitarsus with yellow stripe; small basal spot on middle and hind tibiae. Structure. Ventral surface of hind femur with long hairs on basal 2/5. T7 with median apical projection small, pointed, approximately as broad long. S4 and S5 with sparse apical hairs, not forming distinct apical fimbriae. S6 with median apical notch moderate and without distinct paramedian depressed area.

Etymology. The name of the species refers to the trough-like depression of the paraocular area adjacent to the subantennal and epistomal sutures.

Distribution. Argentina: Entre Ríos, Misiones. Brazil: Santa Catarina.

Material studied. Holotype female, Argentina, Misiones, Parque Nacional Iguazú, Arroyo Yacu-í, IX-1951, R. N. Orfila (MACN). Following paratypes: Argentina. Entre Ríos: 3 F, Pueblo Liebig, XII-1996, XII-1997, 7-X-1997, L. Caire (MLP). Misiones: 3 F, 2 M, same data as holotype (MACN); 1 F, Urugua-í, IX-2005, F. Vossler (MACN); 1 M, Posadas, 31-X-1909, P. Jörgensen (MLP); 1 M, 1 F, "Misiones" 4-II-1910, 22-XI1909, P. Jörgensen (MLP); 16 F, 7 M, Loreto, A. Ogloblin (MLP); 1 F, 1 M, Pindapoy, 17-XI-1945, A. Martínez (MLP); 2 M, Obraje Gilbert, Paraná, 25-III-1940 (MLP). Brazil. Santa Catarina: 1 F, Nova Teutonia, 31-VIII-1955, F. Plaumann (MACN).

\section{Ceratina (Rhysoceratina) catamarcensis Schrottky \\ (Figs. 4B, 6F, 7E)}

Ceratina catamarcensis Schrottky, 1907: 474, 480 (Lectotype female, Catamarca, Argentina, Museo de La Plata, present designation). Schrottky, 1909: 271. Schrottky, 1913: 252. Schlumpberger et al., 2009: 1497.

Ceratina (Rhysoceratina) catamarcensis: Moure, 2007: 645. Rasmussen et al., 2009: 24.

Schrottky's original description (1907) allows the identification of this species with certainty. He mentioned the dark clypeus, the yellowishbrown wing membranes and veins, and the long paraocular yellow band, all of which are characteristic of this Rhysoceratina. The species was already recognized as a Rhysoceratina by Moure (2007). A female specimen with a handwritten label of Schrottky "Ceratina catamarcensis Schrottky" and a printed label "Catamarca" is preserved in the Jörgensen collection in the Museo de La Plata, La Plata, Argentina. It undoubtedly belongs to the type series, and it is here designated as the lectotype. The specimen lacks the prothorax; the head, which lacks the antennae, has been glued to the mesothorax; the metasoma is glued onto a card on the same pin. 

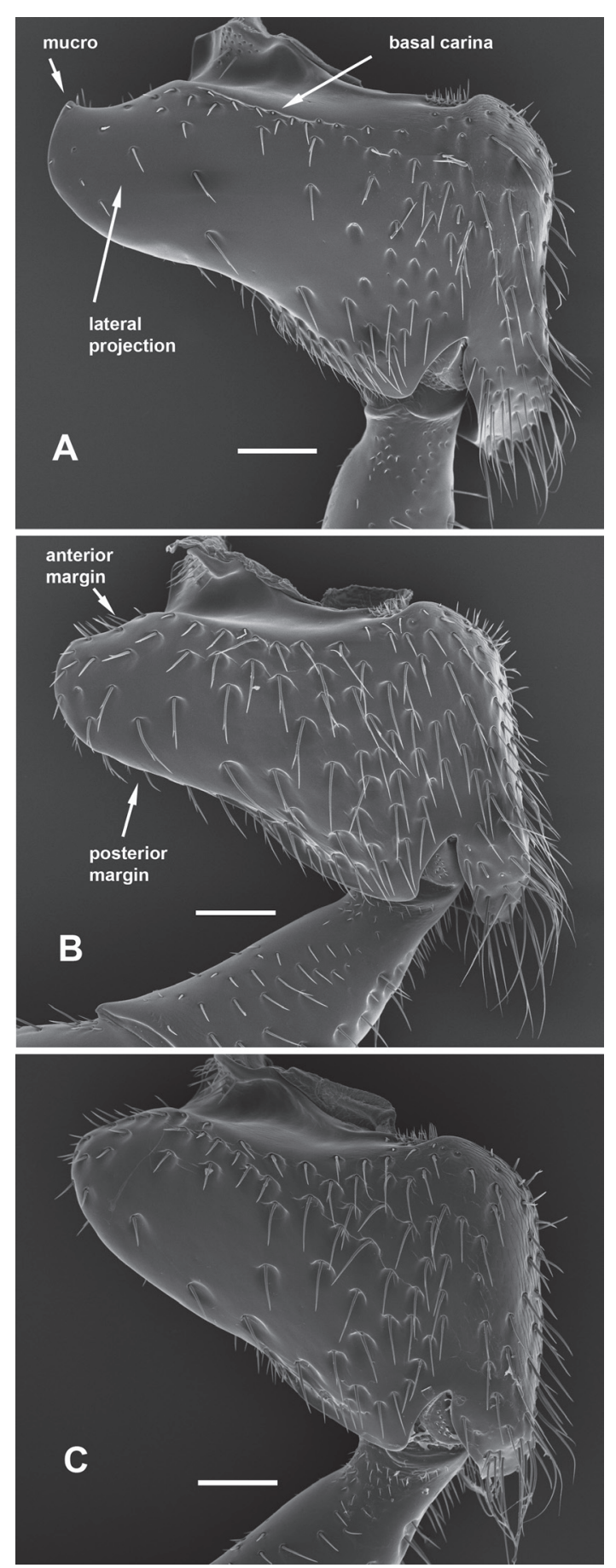

Fig. 3. Forecoxa offemale, anterior view. A, C. mendozina. B, C. pusilla. C, C. correntina. Scale bars: $100 \mu$.

Schrottky did not mention in the original description any yellow on the gena, usually present in this species, but in some specimens, and also in the lectotype, the genal mark is dark brown, barely distinguishable.

Diagnosis. This species is readily distinguished by the color of its wings, with yellowish-brown membrane and veins. The female dark clypeus is only shared with C. montana, from which it is separated by the long yellow paraocular marks and the yellowish-brown wings. The male $\mathrm{T} 7 \mathrm{has}$ a strong, rounded, middle apical projection.

Female. Length, 5.7-8.5 mm; length of forewing 4.5-6.0 mm (lectotype, $4.7 \mathrm{~mm}$ ). Color. Black, with dark olive green metallic tints, in some specimens with coppery reflections on head, scutum and scutellum. Outer half of tegula and apical tarsomeres brown. Clypeus without yellow, in some specimens with dark brown apical band. Paraocular yellow mark long (0.78-0.84 times eye length, lectotype, 0.82), reaching below lateral lower angle of clypeus and surpassing above antennal socket; mark wider than antennal socket diameter, touching in most of its length inner orbit of eye. Gena with yellow mark close to lower third of eye; in some specimens mark orange-brown to dark brown (as in lectotype). Foretibia with basal yellow spot followed by yellow stripe. Wings with yellowishbrown membrane; veins and pterostigma yellowish brown. Structure. Paraocular area punctate from eye to epistomal suture; next to subantennal suture punctate or, sometimes, with narrow smooth area as long as diameter of antennal socket. Distance between lateral ocellus and preoccipital carina 1.55-1.85 times ocellar diameter. Ocellocular area with dense, irregularly distributed punctures, close to ocellus separated by 0.1-0.5 puncture diameter, further apart close to eye. Gena close to upper half of eye with even punctures, separated approximately by a puncture diameter. Proportion between length of eye and length of second segment of labial palpus 1:0.70. Dorsolateral angle of pronotum weakly carinate; lateral carina absent, except sometimes rudimentary on lower sector. Anterior surface of pronotum entirely punctate, punctures reaching dorsolateral angle. Scutum between admedian line and notaulus with punctures irregularly distributed, separated by $0.5-2.0$ times their diameter, interspaces shiny; disc of scutum posteriorly to admedian lines with few scattered punctures. Scutellum with punctures sparse medially, leaving large shiny interspaces, but not forming transverse impunctate band. Dorsal area of metapostnotum rugulose, basally 
with strong rugae, irregular medially and reaching posterior margin. Forecoxa with basal carina; lateral projection of forecoxa with apex squarish, mucronate, anterior margin concave and posterior margin sinuous. T4-T5 with broadened setae. T5 sculptured near to apical margin; apicalmost punctures separated from margin by approximately their diameter. T5 medially moderately flattened, base of tergum not abruptly elevated. $\mathrm{T} 6$ with weak longitudinal median impression.

Male. Length, 5.8-7.5 mm; length of forewing 4.8-5.9 mm. Color. Similar to that of female, with following parts yellow: long paraocular band, separated from subantennal suture by less than its width, extended from upper level of antennal socket to lateral lower angle of clypeus; inverted T-shaped mark on clypeus, pointed above, reaching upper margin of clypeus; triangular spot on base of mandible; basal spot on labrum; spot on pronotal lobe; forefemur with apical spot; foretibia with yellow stripe; small basal spot on middle and hind tibiae. Structure. Ventral surface of hind femur with long hairs on basal 3/5. T7 with median apical projection strong, rounded, approximately as broad as long. S4 and S5 with dense apical fimbriae formed by hairs 1.0-1.5 times MOD. S6 with median apical notch moderate and paramedian depressed area transverse, distinct.

Distribution. Argentina: Catamarca, Jujuy, Salta, Santiago del Estero, Tucumán.

Material studied. Argentina. Catamarca: 1 F, Lectotype of Ceratina catamarcensis Schrottky, "Catamarca" (Museo de La Plata); 1 F, Ambato, Humaya, ex Oxalis sp., J. P. Torretta (MACN). Jujuy: 2 M, Posta de Lozano 26-X-1969, C. Porter (IFML); 1 M, 18-II-1949, Kormilev (MACN); 1 F, Posta de Hornillos, 10-II-1965, A. Willink (IFML); 1 M, Jujuy, Spegazzini (MACN); 1 M, Volcán, 6-XII-2002, B. Schlumpberger (MACN); 1 F, Tumbayá, 20-XI-1989, A. Roig A. (MACN); 2 F, 2 M, Puerta de Lipán, Ruta 52 km18, 10-11X-2009, 2900 m, y.p.t., P. Fidalgo (MACN); 14 F, $1 \mathrm{M}$, Posta de Hornillos, Ruta $9 \mathrm{~km} \mathrm{1762,} \mathrm{2-4-}$ IX-2009 and 10-X-2009, 2380 m, y.p.t., P. Fidalgo (MACN); 1 M, Potrero de Yala, 20-IV-2015, R. González V. (MACN). Salta: 2 F, 1 M, Yacochuya, ca. Cafayate, 8-X-1971, C. Porter \& L. Stange (IFML); $2 \mathrm{~F}, 1 \mathrm{M}$, Yacochuya, $9 \mathrm{~km}$ NW Cafayate, 23-26-IV-1970, L. Stange \& C. Porter (IFML); 1 F, Cafayate, 20-XII-1970, L. Stange (IFML);
5 F, 1 M, Puente del Toro, 14-XI y 15-XI-2002, B. Schlumpberger (MACN); $1 \mathrm{~F}, 40 \mathrm{~km} \mathrm{NW} \mathrm{El}$ Jardín, 13-IV-1977, Halloi \& Fidalgo (IFML); 1 F, 1M, Río Caldera, 1600 m, camino de cornisa, 27II-1992, L. Scaramozzino (CAS); 2 F, 6 M, Finca El Rey, A. Martínez, 21-XI, 29-XI and 1-XII-1952 (MLP). Santiago del Estero: 1 M, Presa Río Hondo, 9-IX-1971, P. Fidalgo (IFML). Tucumán: 1 F, Tucumán, XII-1941 (MLP); 2 F, 1 M, Raco, 1-I-1970 y 18-I-1973, L. Stange (IFML); 1 F, Tafí del Valle, 1-V-1982, A. Willink (IFML); $1 \mathrm{~F}$, Tapia, sin fecha (MACN); 2 F, Trancas, Tacanas, 1-30-XI-1968, L. Stange (IFML); 1 F, Trancas, Tacanas, II-1953, Arnau (IFML); 1 F, Dpto. Tafí, La Sala de San Javier, 9-VI-1973, A. Willink (IFML); 1 F, 1 M, Potrero Las Tablas, 8-V-1981, C. B. de Fernández (IFML); 1 F, 11 km NW El Cadillal, 28-X-2004, A. Roig A. \& L. Compagnucci (MACN); 1 M, San Pedro de Colalao, no date, Arnau (MACN); 1 F, 3 M, San Pedro de Colalao, Arnau (MLP).

\section{Ceratina (Rhysoceratina) correntina Schrottky} (Figs. 2F, 3C, 4D, 6C, 7C)

Ceratina correntina Schrottky, 1907: 475, 480 (Holotype female, Corrientes, Argentina, lost). Schrottky, 1913: 252. Moure, 2007: 647. Rasmussen et al., 2009: 25.

In spite of the loss of the holotype, Schrottky's brief original description allows the identification of this species as a Rhysoceratina. Among the characters that he mentions (Schrottky, 1907), the strongly punctate head and the basal area of the metapostnotum with longitudinal rugae preclude the possibility that the species would belong to the subgenus Ceratinula. The dark body color, small size $(6 \mathrm{~mm})$, and the presence of a longitudinal impression on the T6, indicate that it is not a Calloceratina, the South American species of which are all rather large, bright metallic green, and with an unimpressed T6. The small size, the T1 finely punctate, and the long paraocular yellow band combined with a lack of yellow on the gena, differentiate $C$. correntina from all species of Crewella present in Argentina. The disc of the scutum with punctures, a characteristic stressed by Schrottky, indicates that it is not a species of Neoclavicera, the species of which have a characteristic broad, impunctate area posteriorly to the end of the admedian lines. The pattern of pale marks and the sculpture described by Schrottky fully agree with two morphospecies of Rhysoceratina, both with 

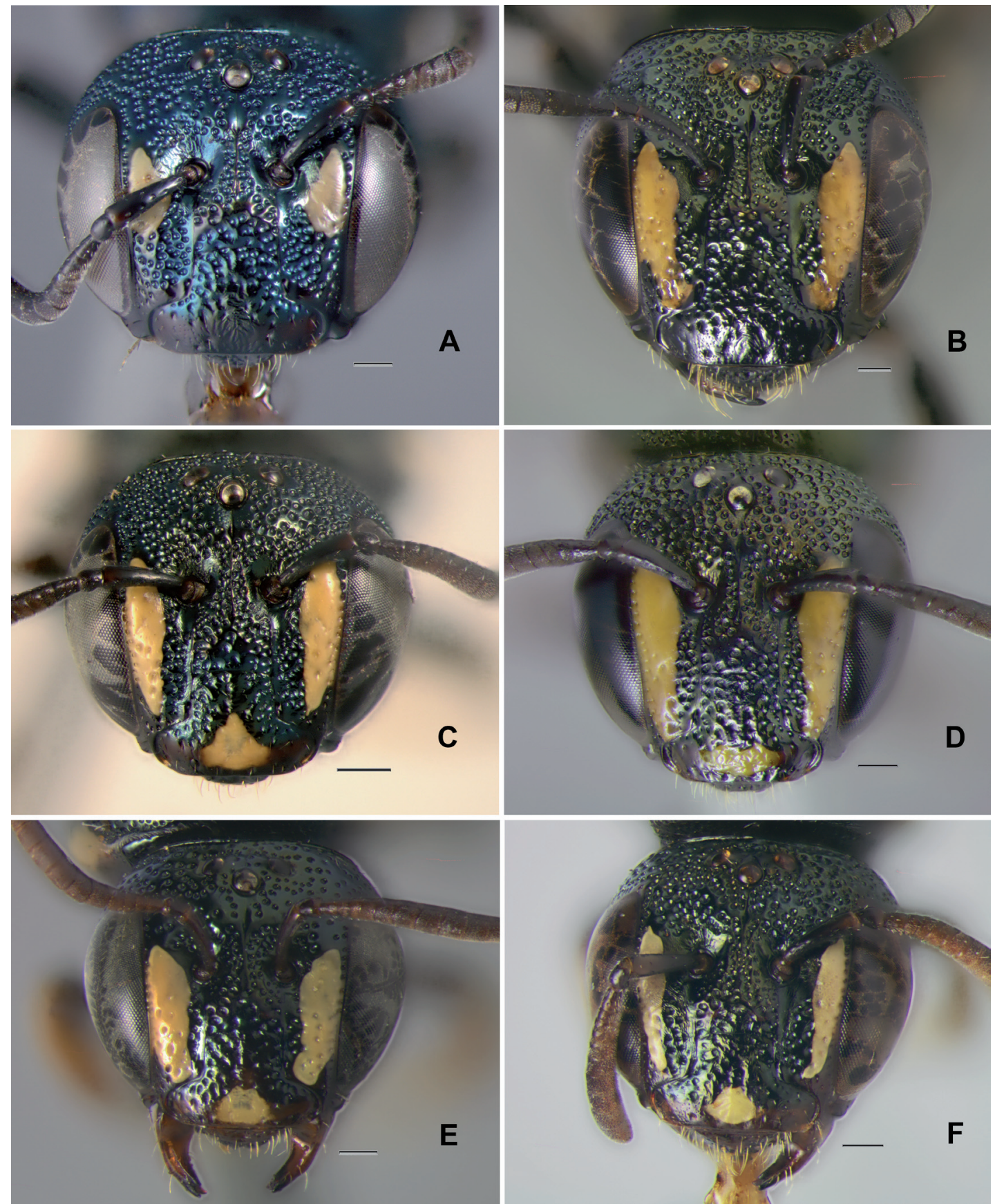

Fig. 4. Head of female, front view. A, C. montana. B, C. catamarcensis. C, C. pusilla, holotype. D, C. correntina. E, C. mendozina, holotype. F, C.volitans. Scale bars: $200 \mu$.

the scutum extensively punctate. One of them, with olive-green body and certain reddish tints, as is described by Schrottky, is here interpreted as $C$. correntina. The second morphospecies, with blue body, is described here as C. pusilla.
Diagnosis. Species closely related to C. pusilla, from which it is separated by the shape of the lateral projection of the forecoxa of the female, with rounded apex, by the yellow paraocular band of the female, truncate below, reaching 
the lateral lower margin of the clypeus, by the dense apical fringe of S5 of the male formed by several rows of hairs, and by the S6 of the male with deep median apical notch and drop-shaped paramedian depressed areas. This shape of the male S6 markedly differs from that of all other species of Rhysoceratina.

Female. Length, 5.6-6.5 mm; length of forewing, 4.1-4.5 mm. Color. Black, with dark olive green metallic tints, in some specimens with reddish reflections on head, scutum and scutellum. Outer half of tegula and apical tarsomeres brown. Yellow spot on clypeus small, rounded. Paraocular yellow mark long (0.80-0.83 times eye length), reaching below lateral lower angle of clypeus and surpassing above antennal socket; mark wider than antennal socket diameter, touching in most of its length inner orbit of eye. Gena black. Pronotal lobe with yellow spot. Foretibia dorsally with basal yellow spot followed by longitudinal yellow band. Wings weakly infuscate; veins and pterostigma brown. Structure. Paraocular area punctate from eye to epistomal and subantennal sutures. Distance between lateral ocellus and preoccipital carina 0.8-1.0 times ocellar diameter. Ocellocular area densely punctate; punctures separated by less than a puncture diameter, coalescent in part. Gena close to upper half of eye with punctures dense, separated by less than a puncture diameter. Proportion between length of eye and length of second segment of labial palpus 1:0.60. Dorsolateral angle of pronotum rounded, without carina; lateral carina absent. Anterior surface of pronotum entirely punctate, punctures reaching dorsolateral angle. Scutum between admedian line and notaulus with punctures dense, separated by less than their diameter, interspaces shiny; disc of scutum posteriorly to admedian lines with abundant punctures separated by 0.5-1.0 times their diameter; scutum with only two slim, longitudinal impunctate bands following notauli. Scutellum with punctures dense, without impunctate median areas. Dorsal area of metapostnotum rugulose, basally with strong rugae, irregular medially and reaching posterior margin. Forecoxa without basal carina; lateral projection of forecoxa with apex rounded, anterior and posterior margins straight. T4-T5 with slender setae. T5 sculptured near to apical margin; apicalmost punctures separated from margin by approximately their diameter. T5 medially moderately flattened, base of tergum not abruptly elevated. T6 with weak longitudinal median impression.
Male. Length, 5.7-6.1 mm; length of forewing 4.3-4.4 mm. Color. Similar to that of female, with following parts yellow: narrow paraocular band, separated from subantennal suture by its own width, extended from upper level of antennal socket to lateral lower angle of clypeus; transverse apical mark on clypeus, in some specimens pointed above, but not reaching above half of clypeus; triangular spot on base of mandible; basal spot on labrum; spot on pronotal lobe; forefemur with apical spot; tibia with yellow stripe; in some specimens with small basal spot on middle and hind tibiae. Structure. Venter of male mesothorax with paramedian sparsely punctate swellings anterior to median depression. Ventral surface of hind femur with long hairs on basal half. T7 with median apical projection short, broad, approximately three times broader than long. S4 with few apical hairs, not forming fimbria, S5 with apical fimbria dense, formed by several rows of hairs, 0.8-1.0 times MOD. S6 with deep median apical notch and paramedian depressed area distinct, drop-shaped.

Distribution. Argentina: Chaco, Corrientes, Entre Ríos, Formosa.

Material studied. Argentina. Chaco: $1 \mathrm{~F}$, Parque Nacional Chaco, 20-IV-2008, A. Taylor (MACN). Corrientes: 1 F, 2 M, Parque Nacional Mburucuyá, Santa Teresa, 31-VIII-2009, 21-IX2009, N. Veiga (MACN). Entre Ríos: 1M, 1 F, El Palmar, 15-IV-2008, A. Taylor (MACN). Formosa: 1 F, Formosa ciudad, Laguna Oca, I-2008, G. Galvani (MACN); 1 M, San Francisco de Laishi, Reserva El Bagual, 1-X-1912, J.P. Torretta (MACN).

Ceratina (Rhysoceratina) mendozina $\mathrm{n}$. sp. (Figs. 2A, 2C-D, 3A, 4E, 5E, 6E, 7D)

Ceratina volitans: Friese, 1908: 43. Jensen Haarup, 1908: 101. Jörgensen, 1909: 60. Jörgensen, 1912a: 138. Jörgensen, 1912b: 313. Schrottky, 1913: 252 (partim). (Specimens from Mendoza, misidentification).

Ceratina (Rhysoceratina) volitans: Moure, 2007: 645646 (partim).

Diagnosis. This species can be recognized by the yellowish-brown anterior tibiae and tarsi, and by the sparse punctation of the head and thorax, being the anterior surface of the pronotum impunctate and polished close to the anterolateral angle. The clypeus of the female has a yellowish-brown apical band, and the small yellow spot is sometimes split in two; the 

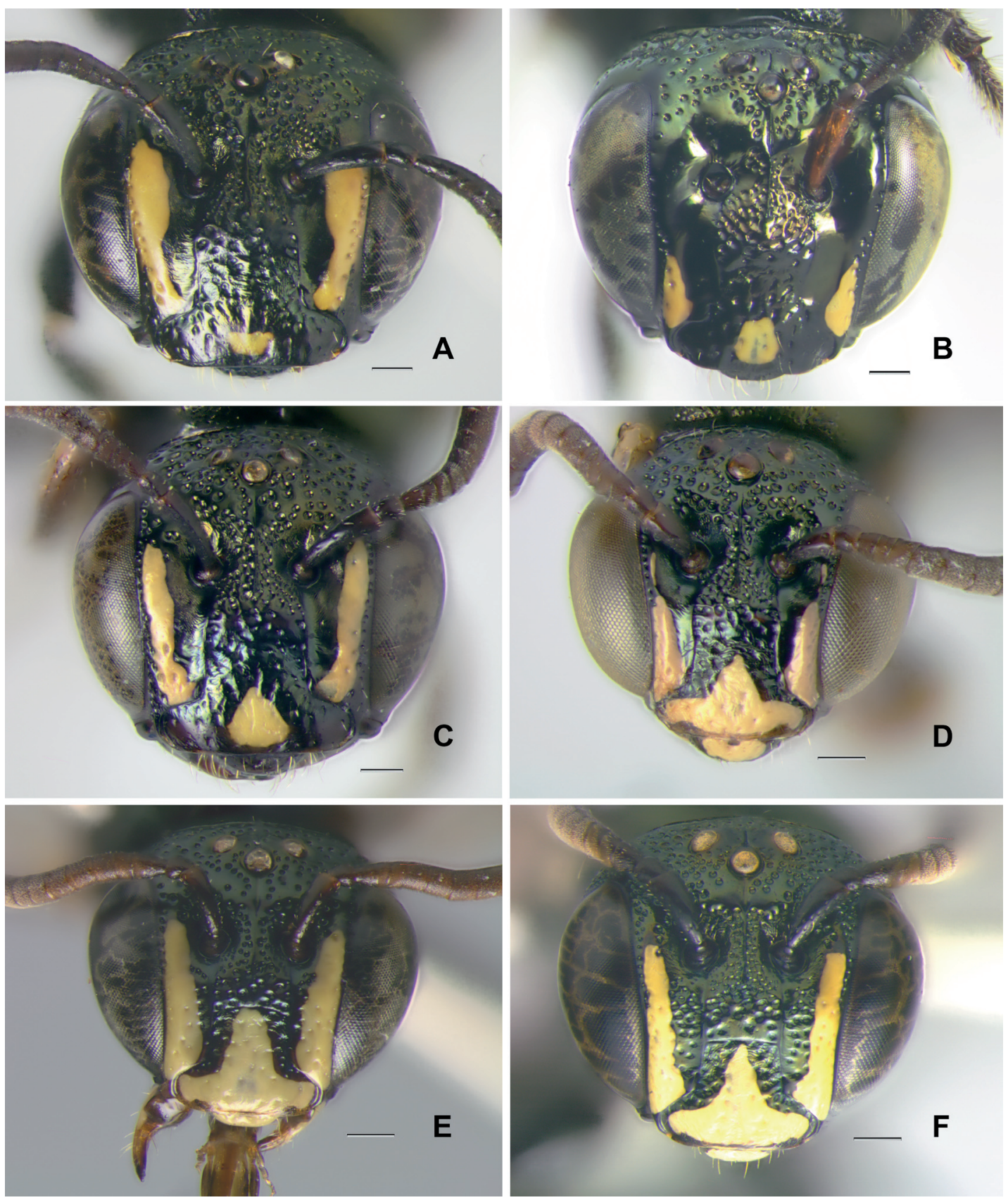

Fig. 5. A-C, Head of female, front view. D-F, Head of male, front view. A, C. stilbonota. B, C. nitidifrons, holotype. C, C. canaliculata, holotype. D, C. canaliculata. E, C. mendozina. F, C. pusilla. Scale bars: $200 \mu$.

yellow paraocular band is broad, above nearly touching the antennal socket. The T7 of the male has a broad apical projection, similar to that of $C$. correntina and C. pusilla, species from which it is separated by the sparse punctation.
Female. Length, 5.2-7.2 $\mathrm{mm}$ (holotype, 6.0 $\mathrm{mm}$ ); length of forewing 4.0-4.8 $\mathrm{mm}$ (holotype, $4.2 \mathrm{~mm})$. Color. Black, with dark blue metallic tints, in some specimens with coppery reflections on head, scutum and scutellum. Foretibia and 
tarsus yellowish brown; mid tibia and tarsus and hind tarsus light brown. Tegula, apical band on clypeus, base of labrum, and outer spot on mandible, yellowish brown to brown. Clypeus with yellow mark variable, in some specimens triangular, reaching above to level of tentorial pits, sometimes reduced to two small juxtaposed spots on the brown apical band. Paraocular yellow mark long (0.70-0.75 times eye length; holotype, 0.70 ), reaching below lateral lower angle of clypeus and surpassing above antennal socket; mark wider than antennal socket diameter, partially touching inner orbit of eye. Gena with brown mark close to lower third of eye; in some specimens upper part of mark yellow. Pronotal lobe withyellow spot. Forefemur with apicalyellow spot; foretibia with basal yellow spot followed by yellow stripe. Wings evenly infuscate; veins and pterostigma brown. Structure. Paraocular area punctate from eye to epistomal suture; next to subantennal suture punctate or, sometimes, with narrow smooth area as long as diameter of antennal socket. Distance between lateral ocellus and preoccipital carina 1.1-1.3 times ocellar diameter. Ocellocular area with few, irregularly distributed punctures, with interspaces as large as a puncture diameter. Gena close to upper half of eye with punctures sparse, irregularly distributed, with some interspaces larger than a puncture diameter. Proportion between length of eye and length of second segment of labial palpus 1:0.60. Dorsolateral angle of pronotum carinate; lateral carina absent, except sometimes rudimentary on lower sector. Anterior surface of pronotum with smooth, shiny area close to dorsolateral angle. Scutum between admedian line and notaulus with punctures irregularly distributed, separated by 1.0-3.0 times their diameter, interspaces shiny; disc of scutum posteriorly to admedian lines with few scattered punctures. Scutellum with punctures sparse medially, leaving large shiny interspaces, but not forming transverse impunctate band. Dorsal area of metapostnotum rugulose, basally with strong rugae, irregular medially and reaching posterior margin. Forecoxa with basal carina; lateral projection of forecoxa with apex squarish, mucronate, anterior margin concave and posterior margin sinuous. T4-T5 with broadened setae. T5 sculptured near to apical margin; apicalmost punctures separated from margin by approximately their diameter. T5 medially moderately flattened, base of tergum not abruptly elevated. T6 with longitudinal median impression.
Male. Length, 4.8-6.0 $\mathrm{mm}$; length of forewing 3.9-4.5 mm. Color. Similar to that of female, with following parts yellow: long paraocular band, separated from subantennal suture by less than its width, extended from upper level of antennal socket to lateral lower angle of clypeus; inverted T-shaped mark on clypeus, pointed above, reaching upper margin of clypeus; triangular spot on base of mandible; basal spot on labrum; spot on pronotal lobe; forefemur with apical spot; foretibia with yellow stripe and forebasitarsus usually also with yellow stripe; small basal spot on middle and hind tibiae. Structure. Ventral surface of hind femur with long hairs on basal 3/5. T7 with median apical projection short, broad, approximately three times broader than long. S4 and S5 with dense apical fimbriae formed by hairs 0.9-1.4 times MOD. S6 with median apical notch moderate and paramedian depressed area transverse, distinct.

Etymology. The specific name refers to the Argentinean province where the type locality is placed.

Distribution. Argentina: Catamarca, Chaco, Córdoba, Formosa, La Rioja, Mendoza, Río Negro, Salta, San Luis, Santiago del Estero.

Material studied. Holotype female, Argentina, Mendoza, Chacras de Coria, 10-I-1990, A. Roig A. (MACN). Following paratypes: Argentina. Catamarca: 2 F, Copacabana, 27-XII,1989, A. Roig A. (MACN); 1 F, Belén, 30-X-1972, L. Stange (IFML); 2 M, Santa María (Río), 7-X1971, Porter \& Stange (IFML). Chaco: 5 F, 1 M, Castelli, XI-2010, F. Vossler (MACN). Córdoba: 3 F, Capital, 25-XI-1948, P. López (IFML); 1 F, Capilla del Monte, 8-II-1976, L. Stange (IFML); 1 F, San Marcos Sierra, quebrada, 24-XII-2006, A. Roig A. (MACN); 1 M, San José, 30-IX-1980, G. Williner (MACN). Formosa: 1 H, San Francisco de Laishi, Reserva El Bagual, ex Senecio grisebachii, 1-X2012, J. P. Torretta (MACN). La Rioja: $1 \mathrm{~F}$, Jagüe, 9-III-1970, Porter \& Stange (IFML); 1 M, La Rioja, 11765, Giacomelli (MACN); 1 F, Nonogasta, XII-1927, M. Gómez (MACN); 1 F, Villa Unión, 22-IV-1972, C. Porter (IFML); 1 M, 7 km S Villa Unión, 28-XI-1977, Willink \& Fidalgo (IFML); 1 F, 6 M, Patquía, 3-X-1954, Hayward (IFML); 1 F, 2 M, Guayapa, 4-X-1954, Hayward (IFML). Mendoza: 4 F, 1 M, Chacras de Coria, 10-I-1990, A. Roig A. (MACN); 1 M, 10 km w Carrizal, 6-I-1990, A. Roig A. (MACN); 2 

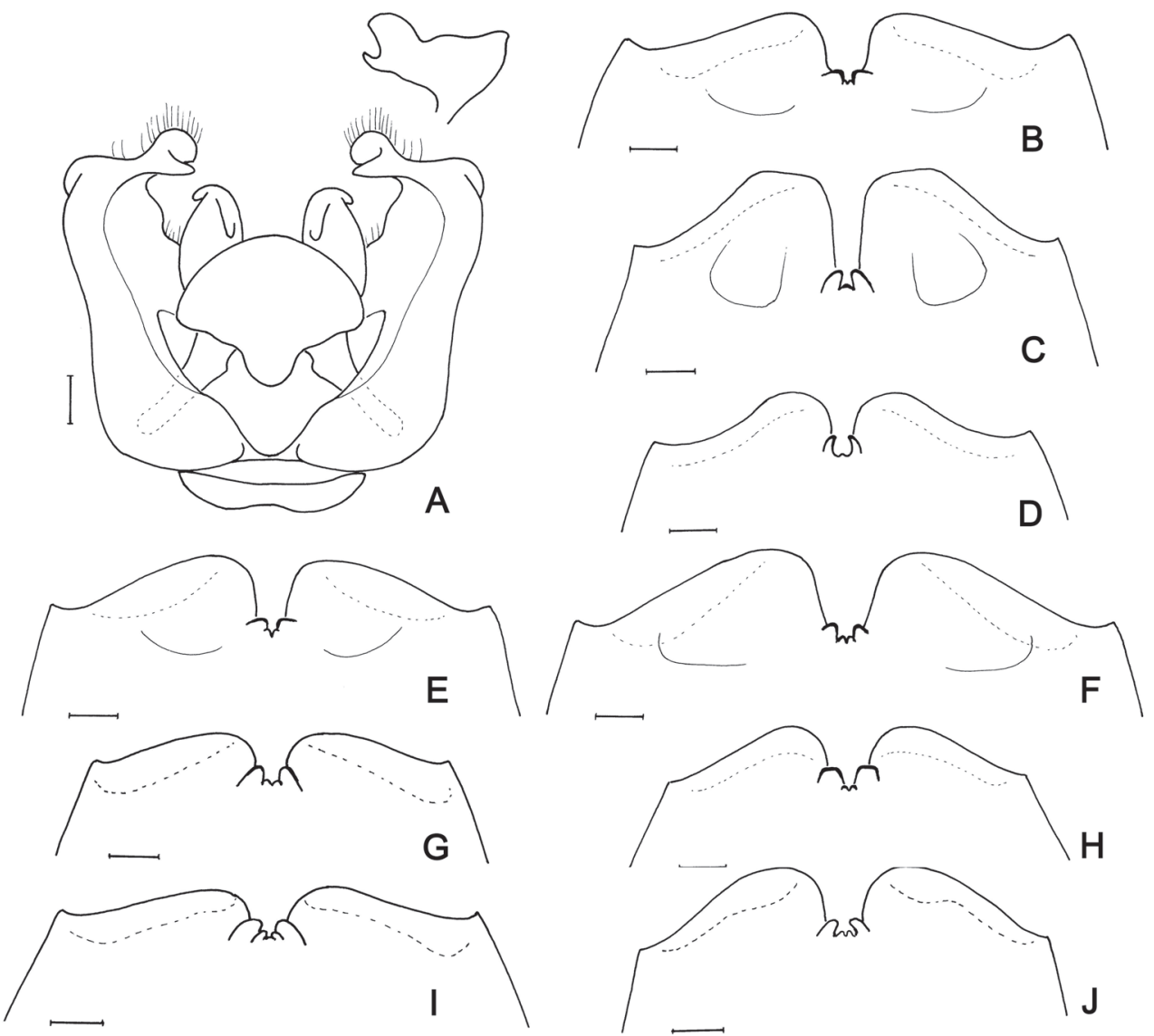

Fig. 6. A, C. montana, genital capsule, dorsal view; above, caudal view of gonostylus. B-J, Apex of sixth metasomal sternum of male. B, C. montana. C, C. correntina. D, C. pusilla. E, C. mendozina. F, C. catamarcensis. G, C.volitans. H, C. canaliculata. I, C. stilbonota. J, C. nitidifrons. Scale bars: $100 \mu$.

F, 2 M, "Mendoza" 29-XI-1906, 25-II-1907, 25IX-1908, P. Jörgensen (MLP); 1 F, San Rafael, 6-I-1940 (MLP). Río Negro: 3 F, 1 M, General Roca, XI-1989, M. Fritz (MACN); 1 F, Paso Córdoba, river 8 km sw Gral. Roca, 7-XI-1997, C. \& M. Vardy (London); 2 F, old INTA stn. ca. $13 \mathrm{~km}$ w Gral. Roca, 8-9-XI-1997 y 25-II-1998, C. \& M. Vardy (London); 1 M, INTA stn. ca. 18 km w General Roca, 6-8-XI-1997 C. \& M. Vardy (London). Salta: 1 F, 1 M, Salta Forestal, 35 km NE Joaquín V. González, 27-XI-1979, Willink, Fidalgo \& Domínguez (IFML). San Luis: $1 \mathrm{~F}$, Cortaderas, 20-II-2005, A. Roig A. (MACN). Santiago del Estero: 1 M, XI-1928, M. Gómez (MACN); 1 M, Termas de Río Hondo, 30-XII1975, L. Stange (MACN); 1 F, 1 M, Termas de Río Hondo, Dique Frontal, 16-X-1971, C. Porter (IFML); 4 F, Termas de Río Hondo, 18-19-IV-1970, L. Stange \& C. Porter (IFML).
Ceratina (Rhysoceratina) montana Holmberg (Figs. 2E, 4A, 6A-B, 7A)

Ceratina montana Holmberg, 1886: 137-138 (Types: females from Tandil, 11-II-1882; and Cerro Claraz, Tandil, XII-1984, C. Solari [province of Buenos Aires, Argentina], lost). Dalla Torre, 1896: 199. Schrottky, 1903: 181. Schrottky, 1907: 475. Schrottky, 1913: 252.

Ceratina tropidura Moure, 1941: 76 (Female holotype, Paraná, Curitiba, 12-XII-1938, Moure, Curitiba). Urban, 2003: 25. New synonym.

Ceratina (Rhysoceratina) montana: Michener, 2000: 599. Michener, 2007: 618. Moure, 2007: 645.

Ceratina (Rhysoceratina) tropidura: Moure, 2007: 645.

Holmberg's original description of this species leaves no doubts about its identity, in spite of the loss of the types. Holmberg (1886) mentioned for the female the presence of a transverse carina on the sixth tergum, as well as a median longitudinal impression. This kind of tergum is unique 
to the subgenus Rhysoceratina. Other characters mentioned, as the black clypeus and the shape and position of the yellow paraocular spot, are diagnostic of the species.

Diagnosis. Females are distinguished by the black clypeus and gena, and by the oblong paraocular spot at level of the antennal socket, shorter than in any other Rhysoceratina, less than half of eye length. The male is distinguished by the small apical triangular projection of $\mathrm{T} 7$ and by the densely punctate scutellum, the punctures leaving no smooth areas between them.

Female. Length 5.5-8.2 mm; length of forewing 4.4-5.3 mm. Color. Black, with dark blue metallic tints. Outer half of tegula and apical tarsomeres 2-4 light brown. Clypeus without yellow, in some specimens with dark brown apical band. Paraocular yellow spot short (0.38-0.42 times eye length), oblong, slightly surpassing upper level of antennal socket above, and not reaching level of upper margin of clypeus below. Gena black, some specimens with difuse dark brown spot in the same position as yellow mark of other species. Foretibia with basal yellow spot. Wings weakly and evenly infuscate; veins and pterostigma dark brown. Structure. Paraocular area punctate from eye to epistomal suture; next to subantennal suture punctate or, sometimes, with narrow smooth area as long as diameter of antennal socket. Distance between lateral ocellus and preoccipital carina 1.15-1.25 times ocellar diameter. Ocellocular area densely punctate; punctures separated by less than a puncture diameter. Gena close to upper half of eye with punctures dense, separated by less than a puncture diameter. Proportion between length of eye and length of second segment of labial palpus 1:0.68. Dorsolateral angle of pronotum rounded, without carina; lateral carina absent, except sometimes rudimentary on lower sector. Anterior surface of pronotum entirely punctate, punctures reaching dorsolateral angle. Scutum between admedian line and notaulus with punctures irregularly distributed, separated by 0.5-2.0 times their diameter, interspaces shiny; disc of scutum posteriorly to admedian lines with few scattered punctures. Scutellum with punctures dense, without impunctate median areas. Dorsal area of metapostnotum rugulose, basally with strong rugae, irregular medially and reaching posterior margin. Forecoxa with basal carina; lateral projection of forecoxa with apex squarish, mucronate, anterior margin concave and posterior margin sinuous. T4-T5 with slender setae. T5 sculptured near to apical margin; apicalmost punctures separated from margin by approximately their diameter. T5 medially moderately flattened, base of tergum not abruptly elevated. T6 with weak longitudinal median impression.

Male. Length, 5.8-6.3 $\mathrm{mm}$; length of forewing 4.0-5.1 mm. Color. Similar to that of female, with following parts yellow: narrow paraocular band, separated from subantennal suture by its own width, extended from upper level of antennal socket to lateral lower angle of clypeus; inverted T-shaped mark on clypeus, pointed above, reaching upper margin of clypeus; triangular spot on base of mandible; central spot on labrum; basal spot and dorsal band on foretibia; in some specimens with small basal spot on middle and hind tibiae; spot on pronotal lobe. Structure. Ventral surface of hind femur with long hairs on basal 3/5. T7 with median apical projection triangular, small. Apical fimbriae of S4-S5 dense, hairs 1.0-1.5 times MOD. S6 with median apical notch moderate and paramedian depressed area transverse, distinct.

Distribution. Argentina: Buenos Aires, Neuquén. Brazil: Paraná. Uruguay: Canelones, Montevideo.

\section{Material studied. Argentina. Buenos Aires:}

2 F, 1 M, Tornquist, Villa Ventana, 18-II-1999, A. Roig Alsina (MACN); 1 F, Tornquist, Ruta 76, pie Cerro Ventana, 20-XII-1997, A. Roig Alsina (MACN); 2 F, Tornquist, Garganta Olvidada, Cerro Ventana, 24-XII-1997, A. Roig Alsina (MACN); 4 F, 1 M, Saavedra, Arroyo Sauce Chico, pie Cerro Gran Chaco, 23-XII-1997, A. Roig Alsina (MACN); 1 F, Cerro El Difunto, Sierras de Tandil, 13-XII-2007, M. Sabatino (MACN); 1 F, Monte Hermoso, I-1972, A. Roig Alsina (MACN); 2 F, 7 M, Monte Hermoso, 26-31-X-2006, L. Compagnucci (MACN); 1 F, Miramar, I-1973, A. Roig Alsina (MACN); 1 M, Vitel, F.C. Sarmiento, IX-1929, J. Daguerre (MACN); 1 M, Tres Arroyos, Claromecó, Vivero, 2-III-2006, A. Roig A. (MACN); $2 \mathrm{M}$, Tornquist, Parque Sierra Ventana, camino Cueva del Toro, 29-II-2000, A. Roig A. (MACN); 4 F, Partido de la Costa, Solimar, 4-III-2012, A. Roig A. (MACN); 1 F, Chascomús, Club San Huberto, 9-I-2012, R. González V. (MACN). Neuquén: 1 F, Zapala (MACN). Uruguay. Canelones: $1 \mathrm{~F}$, Sauce, I-2006, E. Santos (FCM). Montevideo: 1 F, Canteras, 24-XII-1965, F. M. Esc. (FCM). 


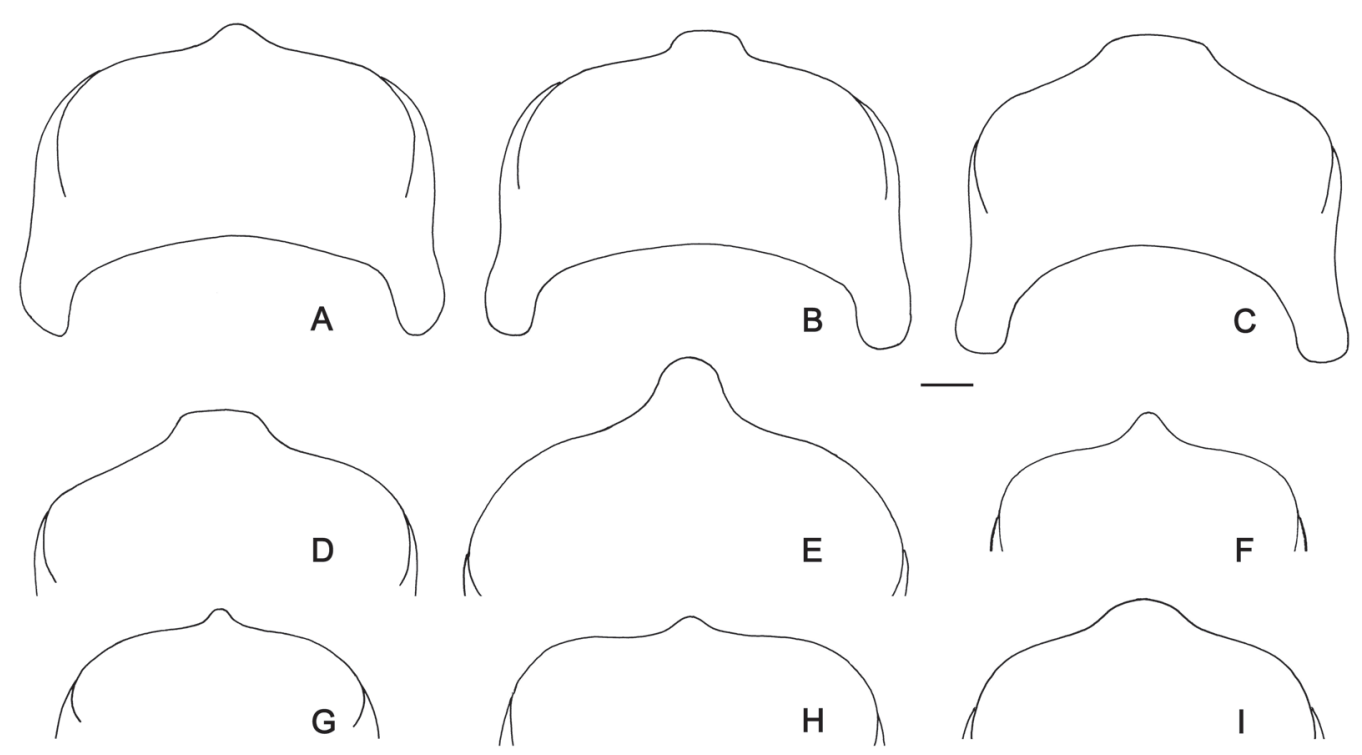

Fig. 7. Apex of seventh tergum of male. A, C. montana. B, C. pusilla. C, C. correntina. D, C. mendozina. E, C. catamarcensis. F, C.volitans. G, C. canaliculata. H, C. stilbonota. I, C. nitidifrons. Scale bar: $100 \mu$.

Ceratina (Rhysoceratina) nitidifrons $\mathrm{n} . \mathrm{sp}$. (Figs. 5B, 6J, 7I)

Diagnosis. This species is distinguished from all other known species of Rhysoceratina by the shape of the female forecoxa, with the rounded lateral projection bent posteriorly, and the polished, impunctate integument above and on outer side of antennal socket in both sexes.

Female holotype. Length, $6.6 \mathrm{~mm}$; length of forewing, $5.0 \mathrm{~mm}$. Color. Black, with dark olive green metallic tints, and reddish reflections on supraclypeal area, scutum and metapostnotum. Antennal scape, inner basal part of foretibia, and tibial spurs reddish brown; tegula and apical tarsomeres dark brown. Clypeus with trapezoidal yellow mark reaching above to level of tentorial pits. Paraocular yellow mark short (0.31 times eye length), reaching below lateral lower angle of clypeus and barely surpassing above upper level of clypeus. Gena with small yellow spot above middle of eye. Pronotal lobe with yellow spot. Forefemur with apical yellow spot; foretibia with basal yellow spot followed by yellow stripe. Wings infuscate, forewing darker along anterior margin of marginal cell; veins and pterostigma brown. Structure. Paraocular area next to subantennal and epistomal sutures depressed, impunctate, smooth, forming a trough reaching below to level of tentorial pit; such a trough 0.6-0.7 times as wide as paraocular area; integument above and on outer side of antennal socket polished, impunctate. Distance between lateral ocellus and preoccipital carina 1.3 times ocellar diameter. Ocellocular area with few, irregularly distributed punctures, leaving large, shiny interspaces. Gena polished, with irregular, longitudinal row of shallow punctures separated from eye by 3-5 puncture diameters. Proportion between length of eye and length of second segment of labial palpus 1:0.63. Dorsolateral angle of pronotum carinate; lateral carina distinct below transpronotal sulcus. Anterior surface of pronotum entirely punctate, punctures reaching dorsolateral angle. Punctures of scutum between admedian line and notaulus dense anteriorly and sparse, irregularly distributed posteriorly; disc of scutum posteriorly to admedian lines impunctate. Scutellum with punctures sparse medially, leaving transverse impunctate band. Dorsal area of metapostnotum rugulose, with few, basal, short rugae laterally and median carina reaching posterior margin. Forecoxa with basal carina; lateral projection of forecoxa long, with apex rounded, directed posteriorly. T4-T5 with slender setae. T5 near to apical margin with median area of sparse punctures. T5 medially weakly depressed; depression not abruptly separated from base of tergum. T6 with longitudinal median impression weak.

Male. Length, 6.0-6.5 mm; length of forewing 4.8-5.0 mm. Color. Similar to that of female, with 
following parts yellow: paraocular band short (0.55 times eye length), reaching below lateral lower angle of clypeus but not reaching above lower level of antennal socket; trapezoidal mark on clypeus, surpassing above level of tentorial pits, but not reaching upper margin of clypeus; irregular spot on base of mandible; basal spot on labrum; spot on pronotal lobe; forefemur with apical spot; foretibia and forebasitarsus with yellow stripe; small basal spot on middle and hind tibiae. Structure. Ventral surface of hind femur with long hairs on basal half. T7 with median apical projection rounded. S4 and S5 with apical sparse, long hairs (0.5-0.6 times MOD), similar to those of S3, not forming distinct apical fimbriae. S6 with median apical notch moderate and with preapical paramedian area punctate, weakly depressed.

Etymology. The specific name refers to the polished face of both sexes in this species.

\section{Distribution. Colombia: Meta.}

Material studied. Holotype female, Colombia, Meta, Villavicencio, Quebrada Honda, 21-VI1974, L. Stange (IFML). Following paratypes: Colombia. Meta: $1 \mathrm{M}$, Villavicencio, Quebrada Honda, 21-VI-1974, L. Stange (IFML); 1 M, 3 mi. W Villavicencio, $920 \mathrm{~m}$, 11-III-1955, E. I. Schlinger \& E. S. Ross (CAS).

\section{Ceratina (Rhysoceratina) pusilla $\mathrm{n}$. sp.} (Figs. 2B, 3B, 4C, 5F, 6D, 7B)

Ceratina pusilla Burmeister, in litteris (MACN).

Diagnosis. This species is distinguished by the densely punctate gena and scutum in both sexes, the color of the head of the female (gena black but clypeus with yellow spot), and the lack of basal carina on the forecoxa. These characters are shared with $C$. correntina, from which it is separated by the shape of the lateral projection of the forecoxa of the female, squarish, not rounded as in C. correntina, by the yellow paraocular band of the female, pointed below, not reaching the lateral lower margin of the clypeus, by the simple row of apical hairs on S5 of the male, not forming a definite fringe, and by the S6 of the male with moderate median apical notch and weakly defined paramedian depressed areas. The male has a pair of sparsely punctate swellings on the venter of the mesothorax, anterior to a median depression. These swellings are also present in correntina, but in no other Rhysoceratina.
Female. Length, 5.5-6.5 mm (holotype, $5.6 \mathrm{~mm}$ ); length of forewing 4.1-4.8 $\mathrm{mm}$ (holotype, 4.1 $\mathrm{mm})$. Color. Black, with dark blue metallic tints. Outer half of tegula and apical tarsomeres brown. Yellow spot on clypeus triangular, reaching above to level of tentorial pit, in some specimens smaller, rounded. Paraocular yellow mark long (0.7-0.8 times eye length), reaching below to lateral lower angle of clypeus and surpassing above antennal socket; mark wider than antennal socket diameter. Gena black. Pronotal lobe with yellow spot. Foretibia dorsally with basal yellow spot followed by longitudinal yellow band. Wings weakly infuscate; veins and pterostigma brown. Structure. Paraocular area punctate from eye to epistomal suture; next to subantennal suture punctate or, sometimes, with narrow smooth area as long as diameter of antennal socket. Distance between lateral ocellus and preoccipital carina 0.65-0.75 times ocellar diameter. Ocellocular area densely punctate; punctures separated by less than a puncture diameter, in some specimens nearly coalescent. Gena close to upper half of eye with punctures dense, separated by less than a puncture diameter. Proportion between length of eye and length of second segment of labial palpus 1:0.60. Dorsolateral angle of pronotum rounded, without carina; lateral carina absent, except sometimes rudimentary on lower sector. Anterior surface of pronotum entirely punctate, punctures reaching dorsolateral angle. Scutum between admedian line and notaulus with punctures dense, separated by less than their diameter, interspaces shiny; disc of scutum posteriorly to admedian lines with abundant punctures separated by 0.5 1.0 times their diameter; scutum with only two slim, longitudinal impunctate bands following notauli. Scutellum with punctures dense, without impunctate median areas. Dorsal area of metapostnotum rugulose, basally with strong rugae, irregular medially and reaching posterior margin. Forecoxa without basal carina; lateral projection of forecoxa with apex squarish, anterior margin weakly concave and posterior margin sinuous. T4-T5 with slender setae. T5 sculptured near to apical margin; apicalmost punctures separated from margin by approximately their diameter. T5 medially moderately flattened, base of tergum not abruptly elevated. T6 with weak longitudinal median impression, in some specimens indistinct.

Male. Length, 5.5-5.8 mm; length of forewing 4.0-4.3 mm. Color. Similar to that of female, with following parts yellow: narrow paraocular 
band, separated from subantennal suture by its own width, extended from upper level of antennal socket to lateral lower angle of clypeus; inverted T-shaped mark on clypeus, pointed above, reaching upper margin of clypeus; triangular spot on base of mandible; basal spot on labrum; spot on pronotal lobe; forefemur with apical spot; tibia and basitarsus of foreleg both with yellow stripe; middle and hind tibiae with small basal spot. Structure. Venter of mesothorax with paramedian sparsely punctate swellings anterior to median depression.Ventral surface of hind femur with long hairs on basal half. T7 with median apical projection short, broad, approximately three times broader than long. S4 with few apical hairs, not forming fimbria, S5 with apical fimbria formed by single row of hairs, 1.0-1.5 times MOD. S6 with median apical notch moderate and paramedian depressed area poorly defined.

Etymology. The specific name pusilla, small in Latin, was left on labels by $\mathrm{H}$. Burmeister, but never published.

Distribution. Argentina: Buenos Aires, Córdoba, Corrientes, Entre Ríos, Formosa, Salta.

Material studied. Holotype female, Argentina, Buenos Aires, Partido Moreno, La Reja, en humedal, 21-X-2001, A. Roig Alsina (MACN). Following paratypes: Argentina. Buenos Aires: 6 F, Moreno, La Reja, en humedal, 21-X-2001, A. Roig Alsina (MACN); 2 F, Florencio Varela, $5 \mathrm{~km}$ SE Bosques, 13-XI-1996, A. Roig Alsina, (MACN); 2 F, Otamendi, 17-II-2000, A. Roig Alsina, (MACN); 10 F, Moreno, La Reja, Reserva F.J. Muñiz, 6-XI-2002, L. Compagnucci \& A. Roig A. (MACN); 1 F, Moreno, La Reja, Reserva F.J. Muñiz, 13-I-2003, A. Roig A. (MACN); 1F, Magdalena, 20-XI-2012, A. Sanguinetti (MACN); 1 F, Tigre, Río Luján, Club ACA, 13-X-2002, A. Roig Alsina, (MACN); $1 \mathrm{~F}$, Tigre, $12 \mathrm{~km} \mathrm{NE} \mathrm{Tigre,}$ 10-XI-1990, A. Roig Alsina, (MACN); 2 F, Junín, I-2009, C. Tellería, (MACN); 1 F, Carlos Casares, Ea. San Claudio, 13-XI-2006, V. Fernández (MACN); 8 F, 1 M, Monte Hermoso, 26-31-X2006, L. Compagnucci (MACN). Córdoba: 1 M, "Cordova" "pusilla Burmeister" (MACN); 3 F Villa Ciudad de América, Dique Los Molinos, I-1981, A. Willink (IFML); 2 F, 22 km S Alta Gracia, 18-19-XI-1975, L. Stange (IFML). Corrientes: 1 F, Parque Nacional Mburucuyá, Santa Teresa, 21-IX-2009, A. Taylor y N. Veiga (MACN). Entre
Ríos: 2 F, Parque Nacional El Palmar, 7-VII2008, A. Taylor \& N. Veiga (MACN); 1F, Depto. Uruguay, Colonia Elía, 26-IV-2012, J.P. Torretta, ex Baccharis pingraea (MACN). Formosa: 1F, Departamento Pilcomayo, XII-1948, I. Morel (IFML). Salta: 1 F, Coronel Moldes, 28-XII-1992, A. Roig A. (MACN); 1 F, Yacochuya, ca. Cafayate, 8-X-1971, C. Porter \& L. Stange (IFML).

\section{Ceratina (Rhysoceratina) stilbonota Moure} (Figs. 5A, 6I, 7H)

Ceratina stilbonota Moure, 1941: 73 (Holotype female, Paraná, Curitiba, 26-X-1939, Moure, Curitiba). Urban, 2003: 25.

Ceratina (Rhysoceratina) stilbonota: Sakagami \& Laroca, 1971: 115. Michener, 2000: 599. Silveira et al., 2002: 147. Michener, 2007: 618. Moure, 2007: 645 .

Diagnosis. This species is readily separated by the black pronotal lobe, without the usual yellow spot present in all other studied species. As in C. canaliculata the T5 is medially depressed on the apical 2/3, but T4-T5 have slender setae, not broadened as in that species, and the gena bears a distinct yellow mark.

Female. Length, 6.2-7.5 mm; length of forewing, 5.0-5.6 mm. Color. Black, with dark olive green metallic tints, in some specimens with coppery reflections on head, scutum and scutellum. Outer half of tegula and apical tarsomeres brown. Clypeus with small, roundish yellow mark not reaching above to level of tentorial pits. Paraocular yellow mark long (0.75-0.77 times eye length), reaching below lateral lower angle of clypeus and surpassing above antennal socket; mark wider than diameter of antennal socket, touching in part inner orbit of eye. Gena with yellow mark behind mid third of eye. Pronotal lobe black, without marks. Foretibia with basal dark brown spot followed by dark brown stripe. Wings evenly infuscate; veins and pterostigma dark brown. Structure. Paraocular area next to subantennal and epistomal sutures depressed, impunctate, smooth or microsculptured, forming a trough reaching below to level of tentorial pit; such a trough 0.4-0.6 times as wide as paraocular area. Distance between lateral ocellus and preoccipital carina 1.6-2.0 times ocellar diameter. Ocellocular area with few, irregularly distributed punctures, with interspaces as large as a puncture diameter. Gena next to upper half of eye without punctures. Proportion between length of eye and length of second segment of labial palpus 1:0.55. 
Dorsolateral angle of pronotum carinate; lateral carina distinct below transpronotal sulcus. Anterior surface of pronotum entirely punctate, punctures reaching dorsolateral angle. Scutum between admedian line and notaulus with punctures irregularly distributed, separated by $0.5-2.0$ times their diameter, interspaces shiny; disc of scutum posteriorly to admedian lines impunctate. Scutellum with punctures sparse medially, leaving transverse impunctate band. Dorsal area of metapostnotum rugulose, basally with strong rugae, irregular medially and reaching posterior margin. Forecoxa with basal carina; lateral projection of forecoxa with apex squarish, mucronate, anterior margin concave and posterior margin sinuous. T4-T5 with slender setae. T5 near to apical margin with median area of sparse punctures. T5 medially with apical two thirds depressed, and base of tergum abruptly elevated. T6 with longitudinal median impression weak or absent.

Male. Length, $6.0 \mathrm{~mm}$; length of forewing $4.6 \mathrm{~mm}$. Color. Similar to that of female, with following parts yellow: paraocular band short, reaching below lateral lower angle of clypeus but not reaching above lower level of antennal socket; inverted T-shaped mark on clypeus, pointed above, not reaching upper margin of clypeus; triangular spot on base of mandible; basal spot on labrum; foretibia with basal spot followed by longitudinal stripe. Structure. Ventral surface of hind femur with long hairs on basal 2/5. T7 with median apical projection small, triangular. S4 and S5 with apical sparse, long hairs (0.6-1.0 times MOD), similar to those of S3, not forming distinct apical fimbriae. S6 with median apical notch moderate and without distinct paramedian depressed area.

Distribution. Argentina: Misiones. Brazil: Paraná, Santa Catarina.

Material studied. Argentina. Misiones: $1 \mathrm{~F}$, ruta El Dorado-Irigoyen, 14-XI-1973, Willink \& Tomsic (IFML). Brazil. Santa Catarina: 2 F, 1 M, São Bento, 22-X-1978, H. Daly (CAS); 1 F, Nova Teutonia, 21-I-1951, F. Plaumann (MACN).

\section{Ceratina (Rhysoceratina) volitans Schrottky} (Figs. 4F, 6G, 7F)

Ceratina volitans Schrottky, 1907: 473, 480 (Lectotype female, present designation, Villa Encarnación, Paraguay, 14-I-1906, California Academy of
Sciences). Strand, 1910: 506, 507. Schrottky, 1913: 252. Cockerell, 1919: 175. Moure, 1941: 75. Laroca, Cure \& Bortoli, 1982: 98.

Ceratina (Rhysoceratina) vollitans (sic): Sakagami \& Laroca, 1971: 97-99, figs. 37-39.

Ceratina (Rhysoceratina) volitans: Silveira et al., 2002: 147. Moure, 2007: 645. Rasmussen et al., 2009: 41.

This is the only species of Rhysoceratina described by Schrottky for which he mentions in the original desciption the lateral carina of the sixth tergum of the female, diagnostic of the subgenus. Schrottky (1907) mentions that he studied nine females and two males from Villa Encarnación, Paraguay. Moure (2007) and Rasmussen et al. (2009) indicate that syntypes of this species are housed at the National Museum of Natural History, Washington, and at the Museu de Zoologia, São Paulo. Specimens of $C$. volitans were not found in the former collection upon my request. Two further syntype specimens have been located in the California Academy of Sciences, San Francisco, and another one in the Museo de La Plata, La Plata, in the P. Jörgensen collection. The specimen in La Plata is broken, only the mesosoma remaining on the pin; it bears the labels "Villa Encarnación 7-IX-1905" and "Ceratina volitans Schrottky," both in Schrottky's handwriting; I have labeled it as paralectotype. The two syntypes housed at the California Academy of Sciences belonged, according to the labels, to Paul Herbst, another German student of bees, who was contemporary with Schrottky and lived in Chile at that time. The specimens are as follows. One female in good condition with two labels in Schrottky's handwriting: "Villa Encarnación 14-I-1906" and "Ceratina volitans Schrottky" plus a printed label "P. Herbst collection Ex Reed." I designate hereby this specimen as the lectotype and label it accordingly. The second specimen is a female that lacks the metasoma, and the head is glued to one of the labels; it is designated as paralectotype. It also has three labels: "Villa Encarnación 4-IX-1905" and "Ceratina volitans Schrottky," both in Schrottky's handwriting, and a printed label "P. Herbst collection Ex Reed."

Diagnosis. This species is distinguished, among species with punctate paraocular areas, by the disc of the scutum impunctate, or with a few punctures posteriorly to the admedian lines. The clypeus has a brown apical band, and the setae on T4-T6 are broadened, as in C. mendozina, species from which it is differentiated by the impunctate or scarcely punctate disc of the scutum, by the 
female T5 depressed medially on the apical $2 / 3$, by the narrower yellow paraocular band of the female, and by the apical margin of the female T5 with a median area of sparse punctures. Other features useful for distinguishing the species and mentioned by Schrottky in the original description are, for the female, the long yellow paraocular band narrowed below, the orangebrown mark on the gena, and the light brown under surface of the flagellum; for the male he mentions the short, sharply defined, middle apical projection of $\mathrm{T} 7$.

Female. Length, 5.6-6.5 mm (lectotype $5.7 \mathrm{~mm}$ ); length of forewing, 4.0-4.5 mm (lectotype 4.2 $\mathrm{mm})$. Color. Black, with dark olive green metallic tints, in some specimens with coppery reflections on head, scutum and scutellum. Outer half of tegula and apical tarsomeres brown. Clypeus with more or less developed brown apical band, and triangular yellow mark frequently reaching above to level of tentorial pits. Paraocular yellow mark long (0.70-0.75 times eye length, lectotype 0.73), reaching below lateral lower angle of clypeus and surpassing above antennal socket. Gena entirely dark, or in some specimens including lectotype with brown mark close to lower third of eye. Pronotal lobe with yellow spot. Foretibia with basal brown spot followed by brown stripe. Wings evenly infuscate; veins and pterostigma brown. Structure. Paraocular area punctate from eye to epistomal suture; below antennal socket, and next to subantennal suture, usually with triangular impunctate area tapering below, as long as 1.5 times diameter of antennal socket. Distance between lateral ocellus and preoccipital carina 1.00-1.25 times ocellar diameter. Ocellocular area with dense punctures, separated by $0.2-0.5$ puncture diameter, further apart close to eye. Gena close to upper half of eye with even punctures, separated approximately by a puncture diameter. Proportion between length of eye and length of second segment of labial palpus 1:0.63. Dorsolateral angle of pronotum carinate; lateral carina usually rudimentary on lower sector. Anterior surface of pronotum entirely punctate, punctures reaching dorsolateral angle. Scutum between admedian line and notaulus with punctures irregularly distributed, separated by 0.5-2.0 times their diameter, interspaces shiny; disc of scutum posteriorly to admedian lines impunctate, or with 2-5 grouped punctures inmediately following lines. Scutellum with punctures sparse medially, leaving paramedian large shiny interspaces (lectotype), in some specimens forming transverse impunctate band. Dorsal area of metapostnotum rugulose, basally with strong rugae, irregular medially and reaching posterior margin. Forecoxa with basal carina; lateral projection of forecoxa with apex squarish, mucronate, anterior margin concave and posterior margin sinuous. T4-T5 with broadened setae. T5 sculptured near to apical margin, except a median area of sparse punctures. T5 medially flattened (smaller specimens) to depressed (larger specimens), at different level of elevated basal third of tergum. T6 with longitudinal median impression.

Male. Length, 5.2-6.0 mm; length of forewing 3.9-4.5 mm. Color. Similar to that of female, with following parts yellow: long paraocular band, separated from subantennal suture by a distance larger than its width, extended from upper level of antennal socket to lateral lower angle of clypeus; inverted T-shaped mark on clypeus, pointed above, reaching upper margin of clypeus; triangular spot on base of mandible; basal spot on labrum; spot on pronotal lobe; forefemur with apical spot; foretibia with yellow stripe. Structure. Ventral surface of hind femur with long hairs on basal $3 / 5$. T7 with median apical projection short, triangular. S4 and S5 with apical fimbriae formed by sparse hairs 0.8 1.1 times MOD. S6 with median apical notch moderate, without paramedian depressed areas.

Distribution. Argentina: Chaco, Entre Ríos, Formosa, Misiones. Brazil: Paraná, Rio Grande do Sul, São Paulo. Paraguay: Itapuá, San Pedro.

Material studied. Argentina. Chaco: $1 \mathrm{~F}$, Resistencia, no date (MACN); 1 F, Resistencia, 4-XI-1945 (MLP). Entre Ríos: Islas del Ibicuy, Quinta Arco Iris, 29-30-XII-2011, Jensen, R-Lutz (MLP). Formosa: 1 F, San Francisco de Laishi, Reserva El Bagual, 1-X-1912, ex Senecio griesebachi, J.P. Torretta (MACN). Misiones: $1 \mathrm{~F}$, San Ignacio, 4-XI-1973, Willink, Tomsic (IFML); 1 F, Puerto Aguirre, III-1934, K. Hayward (IFML); 1 F, 1 km SW Loreto, 3-4-XII-2014, C. Roig (MACN); $1 \mathrm{~F}$, Posadas, 31-X-1909, P. Jörgensen (MLP); 3 F, "Misiones" 22-XI-1909, 10-XII-1909, 10-I-1910, P. Jörgensen (MLP); 10 F, 1 M, Loreto, A. Ogloblin (MLP); 1 F, Pindapoy, 17-XI-1945, A. Martínez (MLP). Paraguay. Itapuá: $1 \mathrm{~F}$, Lectotype Ceratina volitans Schrottky, Villa Encarnación, 14-I-1906 (CAS); 1 F, paralectotype, Villa Encarnación, 4-IX-1905 (CAS); 1 F, paralectotype, Villa Encarnación, 7-IX-1905 (MLP). San Pedro: 1 F, San Estanislao, I-1946, Bridarolli (MACN). 


\section{ACKNOWLEDGEMENTS}

I am grateful to the curators that have loaned material for this study, C. Berta and E. C. Pérez (IFML), D. Notton (London), R. Zuparko (CAS), A. Lanteri and M. Lucía (MLP), E. Morelli (FCM), and to two anonymous reviewers for their helpful comments on the manuscript. I am indebted to F. Tricárico for his help with SEM photographs. This study was funded by CONICET and the Agencia Nacional de Promoción Científica y Tecnológica, Argentina, PICT 2007/1238.

\section{BIBLIOGRAPHY}

Cockerell, T. D. A. 1919. Bees in the collection of the United States Museum.- 3. Proceedings of the United States National Museum 55:167-221.

Dalla Torre, C. G. de. 1896. Catalogus Hymenopterorum, $X$. Lipsiae, viii $+643 \mathrm{pp}$.

Daly, H. V. 1973. Bees of the genus Ceratina in America north of Mexico. University of California Publications in Entomology 74: 1-114.

Friese, H. 1908. Die Apidae (Blumenwespen) von Argentina nach der Reisenergebnissen der Herren A. C. Jensen-Haarup und P. Jörgensen in den Jahren 1904-1907. Flora og Fauna 1908: 1-94.

Goloboff, P., J. Farris \& K. Nixon. 2003. T.N.T.: Tree Analysis Using New Technology. Program and documentation.

Hirashima, Y. 1971. Subgeneric classification of the genus Ceratina Latreille of Asia and West Pacific, with comments on the remaining subgenera of the world (Hymenoptera, Apoidea). Journal Faculty of Agronomy, Kyushu University 16: 349-375.

Holmberg, E.L. 1886. Viajes a las Sierras del Tandil y de la Tinta, Himenópteros. Actas Academia Nacional de Ciencias, Córdoba 5: 137-184.

Jensen Haarup, A. C. 1908. Biological researches amongst the Argentine bees with special reference to flowers they visit. Flora og Fauna 1908: 95-107.

Jörgensen, P. 1909. Beobachtungen über Blumenbesuch, Biologie, Verbreitung usw. der Bienen von Mendoza (Hym.). Deutsche Entomologische Zeitschrift 1909: 53-65.

Jörgensen, P. 1912a. Revision der Apiden der Provinz Mendoza, Republica Argentina (Hym.). Zoologische Jahrbuch, Abteilung für Systematik 32(2): 89-162.

Jörgensen, P. 1912b. Los crisídidos y los himenópteros aculeados de la provincia de Mendoza. Anales Museo Nacional de Buenos Aires 22: 267-338.

Laroca, S., J. R. Cure \& C. Bortoli. 1982. A associação de abelhas silvestres (Hymenoptera, Apoidea) de uma área restrita no interior da cidade de Curitiba (Brasil): uma abordagem biocenótica. Dusenia 13 (3): 93-117.

Maddison, W. P. \& D. R. Maddison. 2016. Mesquite: a modular system for evolutionary analysis. Version 3.10 http://mesquiteproject.org

Michener, C. D. 2000. The Bees of the World. John Hopkins University Press, Baltimore, Mariland. xiv $+913 \mathrm{pp}$.
Michener, C. D. 2007. The Bees of the World. 2nd Ed. Johns Hopkins University Press, Baltimore, Mariland. xvi + 953 pp.

Moure, J. S. 1941. Apoidea Neotropica - III. Arquivos do Museu Paranaense 1: 41-99.

Moure, J. S. 2007. Xylocopini Latreille, 1802. In: Moure, J.S., D. Urban \& G.A.R. Melo (Orgs.), Catalogue of bees (Hymenoptera, Apoidea) in the Neotropical Region. Sociedade Brasilera de Entomología. Curitiba. 1058 pp.

Rasmussen C., B. Garcete-Barrett \& R. B. Gonçalves. 2009. Curt Schrottky (1874-1937): South American entomology at the beginning of the 20th century (Hymenoptera, Lepidoptera, Diptera). Zootaxa 2282: 1-50.

Rehan, S. M., T. W. Chapman, A. I. Craigie, M. H. Richards, S. J. B. Cooper \& M. P. Schwarz. 2010. Molecular phylogeny of the small carpenter bees (Hymenoptera, Apidae, Ceratinini) indicates early and rapid global dispersal. Molecular Phylylogeny and Evolution 55: 1042-1054.

Roig Alsina, A. 2013. El género Ceratina en la Argentina: revisión del subgénero Neoclavicera subg. n. (Hymenoptera, Apidae, Xylocopinae). Revista del Museo Argentino Ciencias Naturales, n. s. 15(1): 121-143.

Sakagami, S. F. \& S. Laroca. 1971. Observations on the bionomics of some Neotropical xylocopine bees, with comparative and biofaunistic notes. Journal of the Faculty of Sciences, Hokkaido University (VI)18: 57-127.

Schlumpberger, B. O., A. A. Cocucci, M. Moré, A. N. Sérsic \& R. A. Raguso. 2009. Extreme variation in floral characters and its consequences for pollinator attraction among populations of an Andean cactus. Annals of Botany 103: 1489-1500.

Schrottky, C. 1903. Enumération des Hyménoptères connus jusq'ici de la R. Argentine, de l' Uruguay et du Paraguay. Anales de la Sociead Científica Argentina 55: 176-186.

Schrottky, C. 1907. Neue und wenig bekannte südamerikanische Bienen. Zeitschrift für Hymenopterologie und Dipterologie 1907: 469-480.

Schrottky, C. 1909. Himenópteros de Catamarca. Anales de la Sociead Científica Argentina 68: 233-272.

Schrottky, C. 1913. La distribución geográfica de los himenópteros argentinos. Anales de la Sociead Científica Argentina 75: 180-286.

Silveira, F., G. A. R. Melo \& E. A. B. Almeida. 2002. Abelhas brasileiras. Sistemática e identificaçao. Belo Horizonte, $253 \mathrm{pp}$.

Strand, E. 1910. Beitrage zur Kenntnis der Hymenopterenfauna von Paraguay. Zoologischer Jahrbuch, Abteilung für Systematik 29: 455-562.

Urban, D. 2003. Catálogo das abelhas publicadas por Jesus Santiago Moure. In: G.A.R. Melo \& I. Alvesdos-Santos (Eds.), Apoidea neotropica: Homenagem aos 90 anos de Jesus Santiago Moure, Editora UNESC, Criciúma, pp. 11-43.

Doi: 10.22179/REVMACN.18.473

Recibido: 11-XI-2016 Aceptado: 13-XII-2016 